\title{
Population trends and status of four seabird species (Uria aalge, Alca torda, Larus fuscus, Larus argentatus) at Stora Karlsö in the Baltic Sea
}

\author{
Populationstrender och status hos fyra havsfågelarter (sillgrissla, tordmule, \\ silltrut, gråtrut) på Stora Karlsö i Östersjön
}

OLOF OLSSON \& JONAS HENTATI-SUNDBERG

\begin{abstract}
The island of Stora Karlsö hosts the largest colonies of fish-eating seabirds in the Baltic Sea. However, recent and reliable estimates of the number of breeding pairs of the main species have been missing. Based on a complete census in 2014, we estimated the number of Common Guillemots Uria aalge to 15700 pairs, more than half (up to $70 \%$ ) of the Baltic Sea population. The number has almost tripled since the early 1970s and the increase has been particularly strong the last 11 years, with an annual increase of $5.1 \%$. We counted 24600 individual adult Razorbills Alca torda and estimated it to correspond to a maximum of 12300 pairs in 2015-2016 (census over two seasons). The colony has grown strongly; on average by $5.6 \%$ annually since the early 1970 s, and Stora Karlsö now hosts up to $30 \%$ of the Baltic Sea population. Stora Karlsö also hosts colonies with about 300 pairs each of

Lesser Black-backed Gull Larus fuscus and Herring Gull Larus argentatus. The gulls' trends are negative, with an average annual decline the last 10 -year period by $5.0 \%$ and $6.2 \%$, respectively.

Olof Olsson, Stockholm Resilience Centre, Stockholm University, Stockholm SE 106 91, Sweden.

E-mail: olof.olsson@su.se

Jonas Hentati-Sundberg, Stockholm Resilience Centre, Stockholm University, Stockholm SE 106 91, Sweden, and Institute of Marine Research, Department of Aquatic Resources, Swedish University of Agricultural Sciences, Turistgatan 5, Lysekil SE 45330, Sweden.

E-mail:jonas.sundberg@slu.se
\end{abstract}

Received 16 September 2016, Accepted 29 March 2017, Editor: Jonas Waldenström

\section{Introduction}

Seabirds are charismatic top predators and have a high conservation value, but can also be valuable indicators of marine ecosystem changes (Cairns 1987, Furness \& Camphuysen 1997, Parsons et al. 2008). The international conventions HELCOM and OSPAR have developed indicators to ensure good conservation status of birds in the Baltic Sea and North Sea regions (ICES 2013, Herrmann et al. 2013). These indicators link to those under development within the European Marine Framework Directive (MSFD), which aims at obtaining Good Environmental Status (GES) in European seas by 2020 (EC 2008). Key to assess these indicators is that relevant seabird populations are identified and monitored with sufficient detail to identify changes in numbers.

The Baltic Sea is one of the best studied marine ecosystems in the world, with many long-term data-series of different ecological and environmental parameters. Sweden has the longest coast of all countries around the Baltic Sea and has national monitoring programs for many aspects of the marine ecosystems, which since 2015 also include coastal and marine birds. The Swedish island of Stora Karlsö $\left(57^{\circ} 17^{\prime} 1 \mathrm{~N}, 17^{\circ} 58^{\prime} 2 \mathrm{E}\right.$, Figure 1), is a key breeding site for seabirds in the Baltic Sea, and this paper will contribute with important and updated information to national and international monitoring.

We provide new information on colony size and trends for four pelagic fish-eating seabird species that breed at Stora Karlsö: Common Guillemot Uria aalge, Razorbill Alca torda, Lesser Blackbacked Gull Larus fuscus fuscus (i.e. the nominate subspecies that mainly breeds in the Baltic Sea, northern Norway and western Kola Peninsula) and Herring Gull Larus argentatus. The two auk 
species have been identified by HELCOM as key species for evaluating the indicator "Abundance of Waterbirds in the breeding season" as one of the core indicators for biodiversity in the Baltic Sea (Herrmann et al. 2013). The two gull species are nationally red listed in Sweden, with Herring Gull having a higher listing than Lesser Black-backed gull (VU and NT respectively) (ArtDatabanken 2015). We discuss the conservation value of the Stora Karlsö colonies in the Baltic Sea context.

\section{Methods}

\section{Common Guillemot - census}

We executed a mainly land-based count of the Common Guillemot colony at Stora Karlsö in 20-23 May 2014. All breeding sites around the island were identified and photographed with an iPad camera (iPad by Apple, Model A1416). We hereafter use the term "ledge" for all breeding sites or spots that we have counted separately and that have a continuous, small or large, group of breeding birds, usually within a natural demarcation. Every single breeding ledge was directly marked on the photo on the iPad screen in the field, and the birds were counted in the field from land with binoculars. Appendix 1 and 2 include photographs of all breeding ledges, geo-coordinates for the counting spots, and raw data on numbers of breeding birds on each ledge. Digital versions of Appendix 1 and 2 (including the photographs) are also stored for the future at Svensk Nationell Datatjänst (SND). They are available at the following online address https://doi.org/10.5878/002919.

We only counted birds that we judged were breeding (seen with, or strong behavioural indication for, egg or chick). This documentation makes it possible to repeat the total count of Common Guillemots in the future, by revisiting sub-colonies and both register change in numbers on each ledge and compare if new ledges have been occupied, or if ledges have been abandoned. Some ledges were not possible to observe from land and for those we instead counted birds on detailed, high quality photographs, that were taken from a small boat on 20 May, 2014 and covering the whole island. The largest sub-colony, Västerberget (area H-K, Figure 1), includes several caves with large numbers of breeding Common Guillemots, where a direct count of birds, from land or from sea, is difficult or impossible. This problem was partly solved by photographs taken with a camera mounted on a pole and held outside the entrance of some of the cave, or other concealed areas. However, for some of the
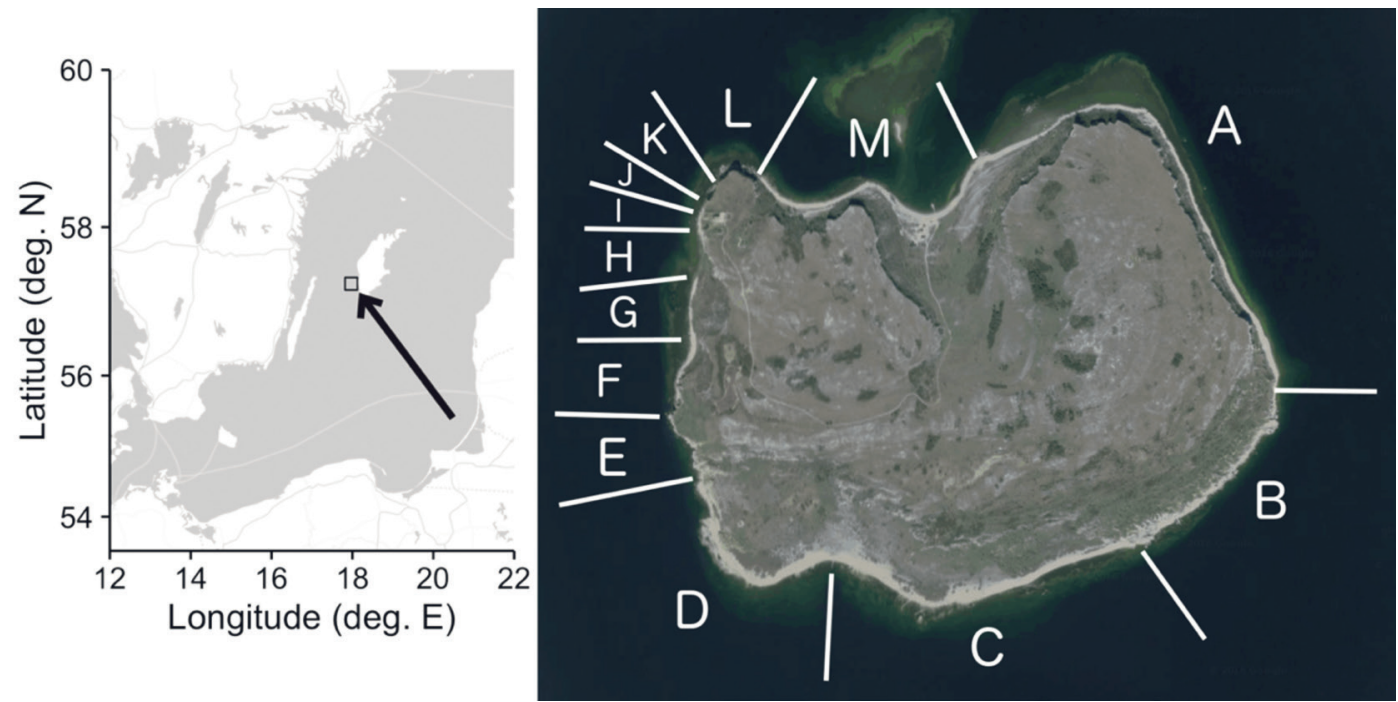

Figure 1. Map showing the location of the island of Stora Karlsö in the central Baltic Sea and the sub-areas of the island, indicated by letters, where we counted birds. For counting numbers, see Table 1. Area names: A - Hassli; B - Svarthällar; C - Eastern Suderslätt; D - Brygge; E - Franska Bukten; F - Stornasar; G - Lerberget; H - Lushålet; I - Fyrhyllan/Röret; J - Rindhålet; K - Korphålet; L - Spangände; M - Hien.

Karta som visar var stora Stora Karlsö är beläget i centrala Östersjön samt räkningsområden på ön, angivna som bokstäver. Siffrorna för de olika områdena och arterna anges $i$ Tabell 1. Se texten ovan för områdenas namn. 
caves, especially Lushålet and Röret (areas H and I, Figure 1), this method was not feasible.

Tocomplement these counts, we used an alternative, indirect method: estimation of sub-colony size by counting fledging chicks. Common Guillemot chicks fledge when they are about three weeks old when they jump from their breeding ledges, at the up to $40 \mathrm{~m}$ high cliffs (Hedgren 1975). At the Västerberget sub-colony, almost all chicks land on a beach below the cliffs before they reach the sea. At this beach, it is possible to catch the chicks, and ringing of fledging chicks has taken place here during a century. Starting already in 1913, and including the 2016 season, 79705 chicks has been ringed at this beach (unpublished data, Bird Ringing Centre, Swedish Museum of Natural History). In 2015, we managed to catch and ring the vast majority ( $\mathrm{n}$ $=4947$ ) of all the chicks landing on the beach. Based on our estimates of breeding success (2015: $70.0 \%, \mathrm{n}=162$, of the pairs managed to raise a chick up to the age of 15 days, method described in Kadin et al. (2012)) and an estimate of catchability for each area, we could use the ringing numbers to back-estimate the number of breeding pairs. The catchability estimate is needed due to the fact that we were unable to catch all the jumping chicks. Chicks are missed due to the following reasons: (i) Some chicks jump before and after the ringing season and during very windy days when ringing was not conducted; (ii) chicks that land directly in water are not possible to catch; (iii) some chicks land on the beach but manage to escape the ringing assistants. Due to the difference between the areas both in terms of how easy it is to catch the chicks on the beach and how many that land in the water, we estimated the catchability to $75 \%, 80 \%, 90 \%$ and $90 \%$ for the four areas $\mathrm{K}, \mathrm{J}$, I and $\mathrm{H}$, respectively (see Figure 1). Our estimate is thus close to the estimate of $85 \%$, for the same parameter for all four areas together, used by Hedgren (1975) in

Table 1. Seabird breeding numbers at the island of Stora Karlsö. The figure for Common Guillemot is an estimate based on 2014, the figure for the areas H and I that was counted in 2015 is adjusted to show 2014 numbers (see Methods). The figure for Razorbill is based on a combined assessment for the field seasons 2015-2016. Note that the number of pairs of Razorbills simply is the number of counted individuals, divided by two. It is therefore the maximum number of pairs (see Methods). The numbers for the two gull species are based on the nest counts in 2016.

Antal häckande havsfåglar på Stora Karlsö i olika delområden. Siffran som anges för sillgrissla gäller år 2014, se Metoddelen). Antalet tordmular gäller säsongerna 2015-2016. Observera att antalet par av tordmule utgörs antalet observerade individer, delat med två. Detta ger det maximala antalet häckade par (se vidare i Metoddelen). Antalet av de två trutarterna är baserat på boräkningar år 2016.

\begin{tabular}{llccccc}
\hline \multirow{2}{*}{ Area } & Area name & \multicolumn{2}{c}{$\begin{array}{c}\text { Common Guillemot } \\
\text { Sillgrissla }\end{array}$} & $\begin{array}{c}\text { Razorbill } \\
\text { Tordmule } \\
\text { pairs (individuals) }\end{array}$ & $\begin{array}{c}\text { Lesser Black- } \\
\text { backed Gull } \\
\text { Silltrut }\end{array}$ & $\begin{array}{c}\text { Herring Gull } \\
\text { Grätrut }\end{array}$ \\
\hline A & Rönnudden, Hassli & 20 & 82 & $6845(13690)$ & 9 & 61 \\
B & Svarthällar & 600 & 1395 & $1107(2460)$ & 109 & 99 \\
C & Äske, Ö Suderhamn & - & - & - & 88 & 116 \\
D & Vinglu, V Suderhamn & - & - & $1845(3690)$ & 44 & 23 \\
E & Franska bukten & 499 & 320 & Included in D & - & 29 \\
F & Stornasar & 2014 & 979 & $565(1130)$ & 11 & 9 \\
G & Lerberget & 187 & - & $415(830)$ & - & 7 \\
H & Lushålet & 3510 & - & $193(385)$ & - & - \\
I & Fyrhyllan/Röret & 2187 & - & $375(750)$ & - & 1 \\
J & Rindhålet & 2094 & - & Included in I & - & - \\
K & Korphålet & 1540 & - & Included in I & - & 1 \\
L & Spangände & 95 & 215 & $829(1657)$ & - & - \\
M & Hien, Norderhamn & - & - & - & - & - \\
& Subtotals & 12746 & 2991 & & & 346 \\
\hline & Total & 15737 & $12296(24592)$ & 261 & \\
\hline
\end{tabular}



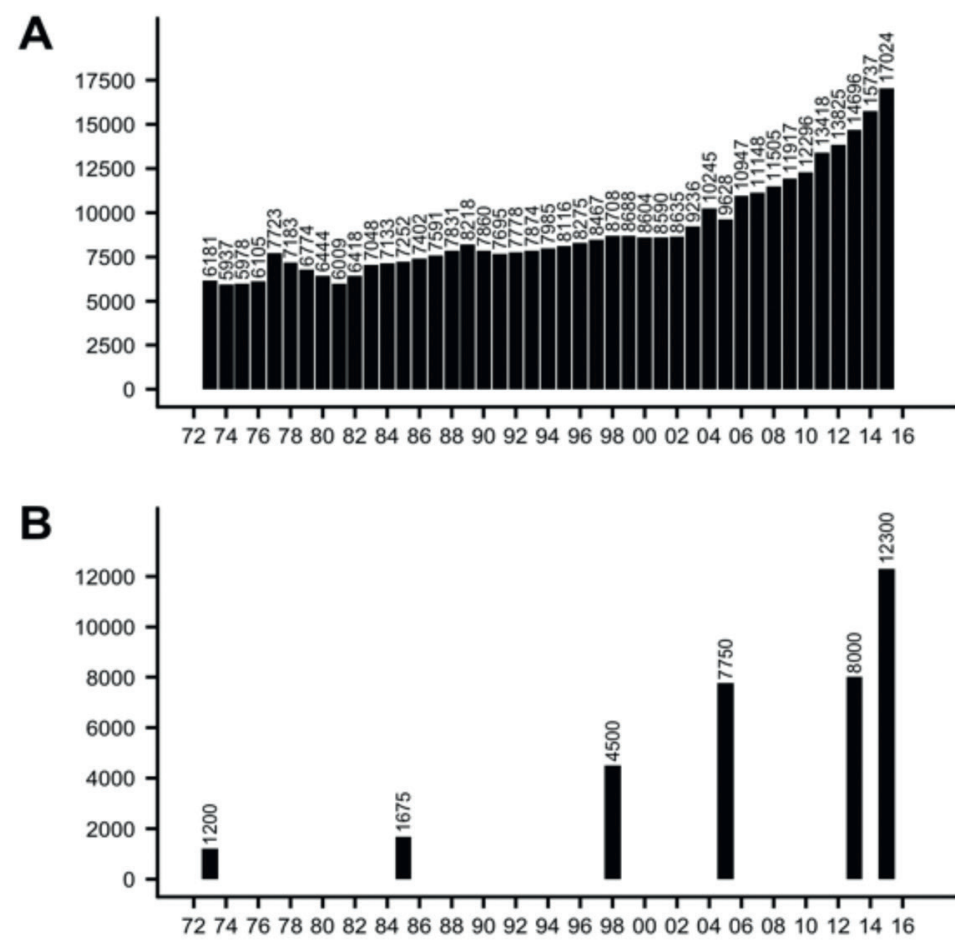

C

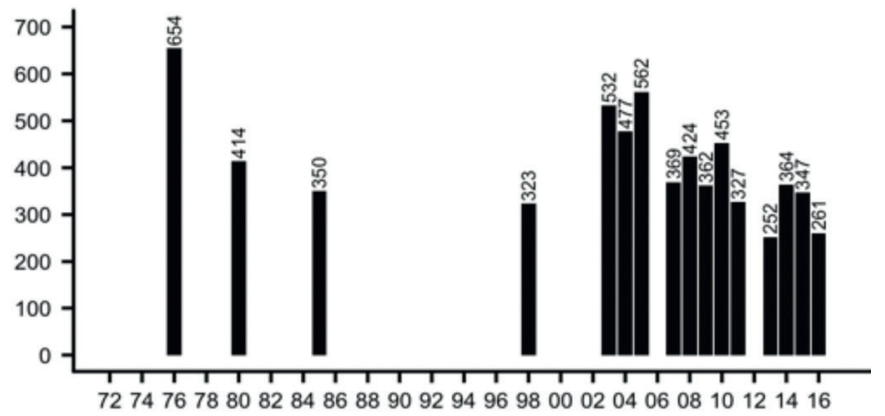

D

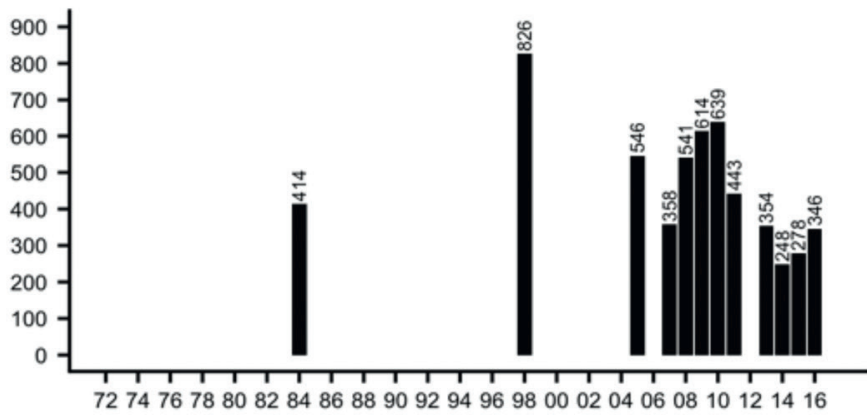

Figure $2 \mathrm{a}-\mathrm{d}$. Trends in numbers of pairs of seabirds breeding at Stora Karlsö. (A) Common Guillemot, (B) Razorbill, (C) Lesser Black-backed Gull, (D) Herring Gull. The Common Guillemot trend estimates were based on a stratified sampling scheme, described in Methods. The Razorbill trend is based on already published data except for new data in 2015-2016. The gull trends are based on complete annual nests counts.

Tidstrender för antalet häckande par av havsfåglar på Stora Karlsö. (A) Sillgrissla, (B) Tordmule, (C) Silltrut, (D) Gråtrut. För sillgrisslorna visar grafen förändringen över tid baserat på fotografier av kolonin. För tordmule redovisas tidigare räkningar, $i$ huvudsak utförda av Länsstyrelsen på Gotland. För trutarna redovisas totalräkningar av bon. 
the early 1970s. As the final total figure for each sub-area, we used either the figure from the direct count or the indirect ringing method, as determined by which method that yielded the highest number. We did so because we consider both methods conservative in estimating the total number of breeding pairs. The indirect ringing-based method gave the numbers for areas $\mathrm{H}$ and I; for the rest of the areas, the census-based method was used. Note that the indirect method used for areas $\mathrm{H}$ and I, was performed in 2015, whereas the total census was done in 2014. This is compensated for in Table 1 and Figure 2, the numbers in Table 1 refer to year 2014 and is adjusted for areas $\mathrm{H}$ and I.

\section{Common Guillemot - colony development}

Since the 1970s, there have been four attempts to estimate the number of breeding Common Guillemots at Stora Karlsö - in 1974, 1985, 2005 and 2013. In 1974, the census was based on the same method as in this study, i.e. a combination of counting jumping chicks at Västerberget and counting birds on the ledges in field and/or from photographs in the other sub-colonies (Hedgren 1975). The three more recent censuses were based on a different method; counting birds at sea in the spring before breeding (Hedgren 1985, Hedgren \& Kolehmainen 2006, Hermansson \& Wizén 2014). We regard these results, especially from 2005 and 2013, as unrealistic given the obvious colony growth presented recently in Hentati-Sundberg \& Olsson (2016) and also given the result of this study (see further in Results and Discussion).

In 2006, we set up a monitoring scheme based on photographing breeding ledges of Common Guillemots at the Stornasar sub-colony (area F, Figure 1). This area covers about $20 \%$ of the entire Stora Karlsö colony. Bases on these photographs, we were able to determine the annual change in numbers. A complicating factor in obtaining a trend estimate that is representative for the entire colony, is that each ledge essentially has its own history of the establishment of breeding pairs. We handled this by dividing the ledges from the 2014 census into three strata: (i) old ledges in the cliffs (those where Common Guillemots have bred at least since the 1970s), (ii) new ledges in the cliffs and (iii) new ledges on the beach. The two latter categories represent fairly recently occupied breeding sites. For each of these strata, we calculated trends based on our photographic surveys (details described in HentatiSundberg \& Olsson 2016). We then combined the annual trend estimates with the 2014 census num- bers to obtain total annual figures. For the birds breeding on the beach, we had no photographic documentation prior to 2006, instead we extrapolated the trend from 2006-2015 backwards in time (beach-breeders were very few before 2006). In this paper, we only report estimates of colony development from 1974 until 2015. The 1974 census by Hedgren (1975), using the same methods as in this study, was used as a further validation of both the trend and the estimate of colony size.

\section{Razorbill - census and colony development}

Because Razorbills, like Common Guillemots, lay their single egg directly on the ground, and most of them breed concealed in-between and under stones, boulders and rocks, direct counts of nest site are not possible. Neither are the indirect methods that we use for Common Guillemots possible to use for estimating Razorbill numbers. Instead we used an alternative indirect method, which previously has been used by the County Administrative Board of Gotland (Länsstyrelsen), namely to count individuals resting at the sea outside the sub-colonies in the spring, about two weeks before the onset of egglaying. We did such total counts in two consecutive years, on 3 May 2015 and on 1 May 2016. Birds observed sitting ashore in the colonies were added to the total numbers. We chose days with no or very little wind, when no or very few Razorbills were seen ashore, and consequently with large numbers of birds resting on the water around the island. The birds were typically concentrated in large, continuous rafts, that could start at the shoreline and continue several hundred (up to 700-800) meters ashore. The weather (calm and sunny conditions), but not the time of the day, seemed to be an important factor for the build-up of rafts. In 2015, we were able to count the birds outside all subcolonies during a single day, whereas in 2016, the right conditions, with no or few birds ashore, were only met for parts of the island. Here we present the largest number of birds counted for each subcolony in any of the years, as we assume that this is the best estimate of the true number of individuals belonging to the colony. In Table 1, we present both number of observed individuals and the maximum number of pairs (i.e. number of individual divided by two). Although this may be an over-estimate of the true number of pairs, it is the only figure that is comparable with previous censuses. We observed very few Razorbills flying away from, or towards, the island on the days of the counts, and thus we assume minimal absence due to foraging. 
Before our censuses in 2015-2016, there have been five attempts since the 1970s to estimate the number of breeding Razorbills at Stora Karlsö; in 1973, 1985, 1998, 2005 and 2013, respectively (Hedgren 1976, Hedgren 1985, Hedgren \& Kolehmainen 2000, Hedgren \& Kolehmainen 2006, Hermansson \& Wizén 2014). On all these occasions, the same method as in this study was used - counting birds resting at sea outside the sub-colonies. We do recognize that this method entails larger uncertainties, compared to the one that we used for Common Guillemots. But given the time and resources available, this method was the only option, and we discuss colony development based on these data.

\section{Lesser Black-backed Gull and Herring Gull - census and colony development}

All active nests of Lesser Black-backed Gull and Herring Gull were counted annually from 2005 to 2016 (expect in 2006 and 2012), in the end of the incubation period, i.e. between 18-28 May for Herring Gull and 29 May-7 June for Lesser Blackbacked Gull. The counts took between 1-2 days for an experienced field crew, ranging between 3 and 6 persons. The number of nests reported includes those with eggs or chicks and also empty nests that we considered as being used during season (either egg not laid yet, clutch predated, or chicks left the nest), following the methodology of Lif et al. (2005).

\section{Results and discussion}

\section{Common Guillemot - census}

The number of breeding pairs of Common Guillemots at Stora Karlsö in 2014 was 15737 (Table 1). The largest sub-colony was Västerberget (area $\mathrm{H}-\mathrm{K}$, Figure 1), located at the north-western corner of the island, with 59\% (9 351) of the pairs. The second largest sub-colony was StornasarFranska bukten (area E-F, Figure 1), situated at the south-western corner of the island, with $24 \%$ (3 812) of the pairs. The third largest sub-colony was Svarthällar (area B, Figure 1), situated at the south-east part of the island, with 13\% (1 995) of the pairs. Photographs of all breeding sites are presented in Appendix 2.

\section{Common Guillemot - colony development}

The Stora Karlsö Common Guillemot colony has increased from about 6000 pairs in 1975 to the estimated 15737 pairs in 2014 (Figure 2a). The colony increased further in 2015 to approximately 17000 pairs. During the 30-year period from 1975 to 2005, the increase was steady but relatively slow, with an annual growth rate of $1.3 \%$ and with a total increase of $58 \%$; from about 6000 to about 10000 pairs (Figure 2a). After that, during the 11-year period from 2005 to 2015, the colony has increased about three times faster, with an average annual growth rate of $5.1 \%$ and with a total increase of $77 \%$; from about 10000 to 17000 pairs. With a continued increase at this rate, we prognosticate the total number of breeding pairs of Common Guillemots at Stora Karlsö to reach 20000 in the year of 2018.

The increase of breeding Common Guillemots at Stora Karlsö has taken place both at newly occupied and at old breeding sites. Since long occupied, and seemingly already crowded, ledges have been even more densely populated, new ledges surrounding old ones have been occupied, but also entirely new breeding areas have been colonized at the island. A particularly striking phenomenon during the recent increase, is that birds have started to use beaches for breeding, especially in areas rich in big boulders. In 2014, about $20 \%$ of the pairs were breeding on beaches, with the largest number, 1395 pairs, at Svarthällar (area B, Figure 1, Table 1. The photograph SNE3 in Appendix 2 illustrates this. Very recently occupied beaches are in areas with boulders at Hassli and Spangände (area A and L, Figure 1), where we foresee further increase in the number of breeding pairs. At Stornasar (area F), the number of beach-breeding pairs has gone from under 100 in 2006 to about 1000 in 2014, and they constituted about $1 / 3$ of the breeding pairs in that sub-colony (Table 1, photograph SNE3 in Appendix 2). So far, only a small fraction of the total area of beaches with boulders are occupied by Common Guillemots, implying that the island's potential breeding space for the species is far from saturated. However, the boulder areas are the main breeding sites for Razorbills and competition for breeding sites between the species may develop in some areas. In fact, at the Stornasar sub-colony (area F), the recent expansion of beach-breeding Common Guillemots, has taken place in areas previously occupied by Razorbills. But because Common Guillemots breed much denser than Razorbills, comparatively few Razorbills are affected by a relatively large expansion of Common Guillemots.

As a complementary and independent method to evaluate the long-term colony change, we compared estimates of the total number of breeding pairs at the Västerberget sub-colony (area H-K, Figure 1) between 2014 and the data that Hedgren 
(1975) reported for 1974. In 1974, the total number was estimated based on counts of 3674 jumping chicks throughout the whole season (3 109 were ringed). This corresponds to $4663 \pm 478$ breeding pairs, given a breeding success of 0.79 (Hedgren 1975). Our result in 2014 was 9351 pairs for the same sub-colony, which was based partly on the same methodology (see above; note that we used a lower figure on breeding success, 0.70, in 2014). This indicates an increase with 101\% (4 688 pairs) at Västerberget over these 40 years. This increase is, however, lower that the estimated increase for the whole island. We suggest that the reason for this is that Västerberget is the core area for the Common Guillemots on the island and that the most suitable breeding ledges were occupied already in 1974 (see e.g. photograph VBL1 in Appendix 2). The potential for increase has therefore been smaller here than at other sub-colonies around the island.

\section{Common Guillemot - earlier analyses of colony development}

In a review of the historical population development until the mid 1970s of the Common Guillemots in the Baltic Sea, with special attention on Stora Karlsö, Hedgren (1975) indicated that the population decreased during the 19th century and that only about 20 pairs remained on the island in the 1880s. In 1880, the Common Guillemots of Stora Karlsö became protected through a private initiative, and the population started to recover. Hence, Stora Karlsö is likely the main source colony for the entire Baltic Sea population of today.

In 1974, Hedgren (1975) made a total census based on the same methodology as our census in 2014, and found 6400 pairs of Common Guillemots at Stora Karlsö. This is very similar to the 6000 pairs in 1975 that we estimate here, based on the photographs in the Stornasar sub-colony (Figure 2a). We regard the difference as negligible and conclude that both these independent estimates show that the size of colony was $6000-6500$ pairs in the mid 1970s. After that, three censuses have been made, in 1985, 2005 and 2013, using a different method: counting birds at sea outside the sub-colonies before breeding onset (Hedgren 1985, Hedgren \& Kolehmainen 2006, Hermansson $\&$ Wizén 2014). The results from these censuses, 7 500, $6000-6500$ and 7000 pairs respectively, suggest a more or less stable colony size in 19852013. Our estimates for these three years, based on the calculation from photographs in the Stornasar sub-colony, were 7250,9600 and 14700 pair, respectively (Figure 2a). Hence, the two methods yield close to similar result for the 1985 colony size, whereas the continued increase of the colony size, shown in our data, is not reflected in the censuses from 2005 and 2013. This suggests that counting birds at sea is a less reliable method for Common Guillemot censuses. Reasons for this are that it is impossible to know if the birds counted on the water are breeders or non-breeders, and whether all breeders are present at a given time. We conclude that the method used by Hedgren (1975) and in this study, is preferable. Moreover, it is important to note that our trend estimate is based on a sub-sample of breeding sites. We have tried to choose a representative sub-sample, but there might still be a bias in the whole island figure in either direction. However, it is obvious that the colony size has increased substantially over time. A reliable estimate of the colony size in the future needs to combine both regular detailed counts of representative sub-areas, with occasional (perhaps every 10 years) complete censuses of the island. The census method, in combination with the 2014 baseline estimate, presented in this paper (see Appendix 1 and 2), provide a good base for this.

In a review of population trends, Ottvall et al. (2009) report an increase in the Swedish population of Common Guillemots during 30 year (1975-2006) and a stable population during the last 10 years of that period (1995-2006). Our study confirms the long-term increase, but rather show a moderate but steady increase also the last ten years of that period (Figure 2a).

\section{Razorbill-census}

In the seasons 2015-2016, we counted about 24600 individuals of Razorbill, mainly at sea (but also some ashore) outside to the different sub-colonies at Stora Karlsö (Table 1). Assuming an equal sex ratio and that all were breeding birds, this corresponds to a maximum of 12300 pairs. Because it is impossible to know if all the counted individuals are breeding birds (some might for example be young, 1-3 year, non-breeding individuals), we suggest that the number of breeding pairs at Stora Karlsö were in the range of 10 000-12 300. The sub-colonies at the southern part of the island (Svarthällar, Suderhamn and Franska bukten; areas B-D), were estimated to a maximum of 3075 pairs ( $25 \%$ of the entire colony), and showed very similar numbers in the two census years. The sub-colonies at the eastern part of the island (Rönnudden-Hassli; area A) were estimated to maximum 6845 pairs 
(56\% of the entire colony), and showed large differences between the two years. The sub-colonies at the western part of the island (Stornasar, Lerberget, Västerberget and Spangände; areas F-L) were estimated to maximum 2375 pairs (19\% of the entire colony), and were only possible to count in 2015 . The proportion of estimated breeding birds in these three areas fits well with our general impression of the distribution of birds and occupied breeding habitats around the island. The estimates imply that the main concentrations of Razorbills are on the eastern side of the island, whereas most Common Guillemots breed on the western side, something that corresponds well with earlier studies (Hedgren \& Kolehmainen 2006).

\section{Razorbill - colony development}

We present no new data on colony development for Razorbill in this paper. However, in Figure $2 b$ we report our estimate from this study, in relation to previous censuses at Stora Karlsö. These indicate that the colony has grown from roughly 1000 to maximum 12300 pairs in 40 years. Given the numbers reported in Figure 2b, the increase over the period has been on average $5.6 \%$ annually. Above we concluded that the method of counting Common Guillemots at sea is not reliable. Unfortunately, for Razorbills at Stora Karlsö, there exists no data derived from other methods. We suggest that ideally a similar method that we used for the total census of Common Guillemots in 2014, should be used also for the Razorbills; i.e. mapping all breeding sites (sub-colonies) and count, or estimate, the number of pairs (or density) in all sub-colonies. Still, the general impression of the colony development of Razorbills at Stora Karlsö, with steadily more birds in already established areas and also with colonization of new areas, fits very well with the trend from these censuses (Figure 2b). However, our census in 2015-2016, (maximum 12300 pairs) differs substantially from the census in 2013 by Hermansson \& Wizén (2014) (8 000 pairs) (Figure 2b), indicating weaknesses in this method for Razorbills too. Nevertheless, we conclude that the results from the censuses, except the one made in 2013, fits well

Table 2. The number of pairs, and comparisons of proportions, of four seabird species censuses at Stora Karlsö (in 2014,2015 or 2016; this study) in relation to the number of pairs for the Swedish part of Baltic Sea and the entire Baltic Sea. We have defined the Baltic Sea to include all waters south and east of a line between the north-western border of Skåne in Sweden and Grenå in Denmark. For the total numbers in the Swedish counties (län), we have used the figures given in Ottoson et al. (2012). Note that this may include pairs of the two gull species that are breeding inland in these counties. The number of pairs in the entire Baltic Sea of the two auk species are retrieved from reviews in Herrman et al. (2013). Note also that the census data from Stora Karlsö are from later dates than for the other areas, see text for details.

Antal häckande par sillgrissla, tordmule, silltrut och gråtrut på Stora Karlsö i relation till resten av den svenska Östersjökusten och hela Östersjön. Vi har definierat Östersjön att inkludera allt vatten söder och öster om en linje mellan det nordvästra hörnet av Skåne och Grenå i Danmark. Den totala siffran för Sverige är baserad på Ottosson m.fl. (2012). Notera att siffran för kustlänen också innehåller en del inlandshäckande trutar. Antalet alkor i hela Östersjön är baseras på en sammanfattning av Herrman m.fl. (2013). Notera att totalräkningarna från Stora Karlsö är från senare datum än de övriga områdena, se texten för detaljer.

\begin{tabular}{lcccc}
\hline & $\begin{array}{l}\text { Common } \\
\text { Guillemot } \\
\text { Sillgrissla }\end{array}$ & $\begin{array}{l}\text { Razorbill } \\
\text { Tordmule }\end{array}$ & $\begin{array}{l}\text { Herring } \\
\text { Gull } \\
\text { Gråtrut }\end{array}$ & $\begin{array}{l}\text { Lesser Black- } \\
\text { backed Gull } \\
\text { Silltrut }\end{array}$ \\
\hline $\begin{array}{l}\text { Number of pairs Antal par } \\
\text { Stora Karlsö }\end{array}$ & 15700 & 12300 & 350 & 260 \\
Sweden (Baltic Sea part) & 20640 & 29905 & 38200 & 8848 \\
Baltic Sea & 23540 & 39115 & - & - \\
& & & & \\
Proportion of breeding pairs at Stora Karlsö in relation to the total for: & & $3 \%$ \\
Andel häckande par på Stora Karlsö i förhållande till totalsumman för: & & - \\
Sweden (Baltic Sea part) & $78 \%$ & $41 \%$ & $1 \%$ & - \\
Entire Baltic Sea Hela Östersjön & $68 \%$ & $31 \%$ & & \\
\hline
\end{tabular}


with the general impression of an overall strong increase of the colony. It also reflects a similar colony development as for the Common Guillemots (Figure $2 \mathrm{a}$ and $2 \mathrm{~b}$.)

In the review of population trends, Ottvall et al. (2009) reported a significant increase in the Swedish population of Razorbills both during a 30 -year period (1975-2006) and in the last 10 years of that period (1995-2006). Our result from Stora Karlsö seems to reflect the same overall colony development (Figure 2b).

\section{Lesser Black-backed Gull and Herring Gull- censuses and colony developments}

The number of breeding pairs of Lesser Blackbacked Gulls has varied between 562 and 261 in the period 2005-2016 of this study (Figure 2c). We have also added previously reported annual counts, back to 1976; numbers prior to 2005 reprinted from Fredriksson (1992) and Lif et al. (2005). The data since 2005 show a significant decrease, averaging 5.0\% per year. The two years (2013 and 2016) with the lowest numbers of breeding pairs occurred within the lasts four years (Figure 2c).

The annual total number of breeding pair of Herring Gulls has varied between 639 and 248 in 2005-2016 (Figure 2d). We have also added two previously reported annual counts, 1984 and 1998 (Hedgren 1985, Hedgren and Kolehmainen 2000). Also, Herring Gulls have been decreasing since 2005 with an average rate of $6.2 \%$ per year. The two years (2014 and 2015) with the lowest numbers of breeding pairs occurred within the lasts three years (Figure 2d).

The inter-annual variation in the gull nest numbers is considerable, which can be both a result of the difficulty of detecting nests, which partly is related to the thickness of the undergrowth (see Lif et al. 2005), but maybe also due to the fact that not all adult gulls breed each year. In any case, we consider the observed trend estimate robust to such inter-annual variation.

In their review, Ottvall et al. (2009) reported that the Swedish Lesser Black-backed Gull population (sub-species Larus fuscus fuscus, that breeds in the Baltic Sea) had been stable in a ten-year period, 1995-2006, and that the Herring Gull population had decreased. Data presented in Figure 2c indicate a stable colony size, or even an increase in the Stora Karlsö colony of Lesser Black-backed Gull, in the late 1990s and early 2000s. This is in line with the trend for the Baltic Sea reported by Ottvall et al. (2009). However, the last ten years of this study show a decrease in Lesser Black-backed Gulls. Although we have few data on Herring Gulls for the period 1995-2006, this study confirms the decrease (Figure 2d), reported by Ottvall et al. (2009).

The counting of gull nests entails some disturbance. Our impression is that this has not influenced the gulls' breeding success at Stora Karlsö. But because both gull species are red-listed, the populations are decreasing, and the fact that we cannot totally exclude that the censuses have had a negative impact, we recommend that the gull censuses are done less frequently in the future, perhaps at an interval of three to five years unless there are specific scientific questions motivating a higher interval, and that all other types of non-necessary disturbances are minimized.

\section{Significance of the Stora Karlsö seabird colonies}

Because neither the auk nor the gull populations are stable and different sub-populations or colonies may have different trends over time, and because data on colony and population sizes derive from different years (between this study and published data from other colonies), it is not possible to make precise estimates of how large proportion the Stora Karlsö colonies constitute of the Swedish or the entire Baltic Sea populations. Nevertheless, to get a rough idea of the proportions, in Table 2 we compare the most recent results from this study with the most recent published numbers of breeding pairs of the four species for the total populations in the Swedish part of the Baltic Sea and for the entire Baltic Sea. This comparison indicates that the Stora Karlsö colony is a very important locality for the two auk species. For Common Guillemots, Stora Karlsö hosts at least half, and perhaps up to $70 \%$, of the entire Baltic Sea population and up to $80 \%$ of the Swedish population. The corresponding numbers for Razorbills is up to $30 \%$ of the entire Baltic Sea population and up to $40 \%$ of the Swedish population. A problem with these comparisons are that the data on colony size from Stora Karlsö are from later dates than all other data. Hence, if there is a general positive trend for a species in the whole region, including Stora Karlsö, this means that the figures on colony size from Stora Karlsö could be larger than those from other areas that have be counted earlier, and vice versa. We may therefore over-estimate the proportion of auks and under-estimate the proportion of gulls at Stora Karlsö. However, for Common Guillemots, there may have been a decrease, or a less strong increase, in the number of breeding pairs in some areas, at 
least along the Swedish coast, due to predation or disturbance from an increasing population Whitetailed Eagles Haliaeetus albicilla (U. Lötberg, pers. com.).

\section{Reasons for population change}

In this study, we do not present data on any environmental parameter that might influence the seabird populations. Neither is the ambition to provide an extensive review of possible such parameters. However, we still want to give some hints on possible explanations to the results, that might be interesting to explore more in depth in the future.

A striking result from this study is that we have shown long-term trends for four seabird species that to a large extent is dependent on the same food resource (small pelagic schooling fish - European Sprat Sprattus sprattus and Herring Clupea harengus) (Lyngs, 2001, Lyngs \& Durinck 1998, Kadin et al. 2016, Schönberg Alm 2007, unpublished data). Two of them, the auks, are increasing in numbers whereas the two others, the gulls, are decreasing.

Generally, the abundance of Sprat and Herring seem to have been good, although with some variation, throughout the last 40 years covered in this study. Good food availability is a prerequisite for seabird population growth, which especially the two auk species seem to have benefited from. The increase of Common Guillemots shows a clear acceleration the last ten, or so, years (Figure 2a). Our results indicate the same pattern also for Razorbills, although the data are less reliable (Figure 2b). The reason for this acceleration is probably not that the food has become even more abundant, but rather lower mortality rates for young and adult birds. It coincides with the ban on driftnet fishing (HentatiSundberg et al. 2015) and, thus, one explanation might be lower bycatch rates in fishing gear (see also Österblom et al. 2002). During the last 40-50 years, also the ban of hunting of the auks, fewer oil spills and lower concentrations of some key environmental pollutants, such as DDT and PCB, potentially have had positive effects on the auk populations (Olsson et al. 2000, Bignert \& Helander 2015).

The figures of annual increase of both auk species at Stora Karlsö, about $5 \%$, are similar to those reported from Skomer Island, at the Welsh coast, and which are suggested to be at the population's intrinsic rate of increase (Meade et al. 2013).

Historically, the gulls have benefited from discards from fishing vessels and this recourse has likely decreased dramatically in the last decades due to a contraction of the cod stock and diminished cod fisheries, in the area close to Stora Karlsö (Casini et al. 2012). The decrease in this food resource may have influenced the gulls' numbers in the early part on this study, but probably less so during the last 20 years. The change in land-fill management in northern Europe may have had a negative effect on winter survival of Herring Gulls. The fuscus-subspecies of Lesser Black-backed Gull migrates to northern and central Africa and changed conditions at migration routes, or in winter quarters, may have contributed negatively to survival rates. We have also observed poor breeding success at Stora Karlsö, especially for Lesser Black-backed Gulls, but the reason for this is unknown (Lif et al. 2005).

\section{Conclusions}

- Stora Karlsö is a key colony with over half, perhaps up to $70 \%$, of the Common Guillemots and up to $30 \%$ of the Razorbills in the Baltic Sea. Monitoring the colony developments of these species at Stora Karlsö is critical for evaluating the HELCOM breeding seabird indicator for the Baltic Sea region.

- Conservation measures that enhance adult survival, such as driftnet ban, appear to have had a strong positive effect on the auk populations.

- The colonies of Lesser Black-backed Gull and Herring Gull are decreasing steadily at Stora Karlsö. We see no obvious explanation for this ongoing decrease.

- Integrating seabirds with other ecosystem components, such as forage fish populations, bycatches, discards, environmental contaminants and oil spills, is important to assess future sustainability of the populations.

\section{Acknowledgements}

We thank Karlsö Jagt- och Djurskyddsförenings AB and WWF Sweden for long-term support and cooperation. We thank Aron Hejdström, PA Berglund, Rebecca Young, Martina Kadin, Eva Kylberg, Ebba Willerström and several other field workers for assistance during fieldwork. Aron Hejdström also processed all photographs presented in Appendix 2. We are grateful to two referees for useful suggestions on how to improve the manuscript.

\section{References}

ArtDatabanken. 2015. Rödlistade arter i Sverige 2015. ArtDatabanken SLU, Uppsala.

Bignert, A. \& Helander, B.O. 2015. Monitoring of con- 
taminants and their effects on the Common Guillemot and the White-tailed sea eagle. Journal of Ornithology. doi:10.1007/s10336-015-1240-3

Cairns, D.K. 1987. Seabirds as indicators of marine food supplies. Biological Oceanography 5: 261-271.

Casini, M., Blenckner, T., Möllmann, C., Gårdmark, A., Lindegren, M., Llope, M., Kornilovs, G., Plikshs, M. \& Stenseth, N.C. 2012. Predator transitory spillover induces trophic cascades in ecological sinks. Proceedings of the National Academy of Science. doi:10.1073/pnas.1113286109

EC, 2008. DIRECTIVE 2008/56/EC OF THE EUROPEAN PARLIAMENT AND OF THE COUNCIL of 17 June 2008 establishing a framework for community action in the field of marine environmental policy (Marine Strategy Framework Directive).

Fredriksson, R. 1992. Silltruten på Stora Karlsö och dess status på övriga Gotland. Bläcku 18: 21-31

Furness, R.W. \& Camphuysen, C.J. 1997. Seabirds as monitors of the marine environment. ICES J. Marine Science 54, 726-737. doi:10.1006/jmsc. 1997.0243

Hedgren, S. 1975. The breeding population of Guillemot Uria aalge in the Baltic Sea. Vår Fågelvärd 34: 43-52.

Hedgren, S. 1985. Häckande fåglar på Stora Karlsö 19841985. Länsstyrelsen i Gotlands län.

Hedgren, S. 1976. Stora Karlsö - en gotländsk fågelö. - I: Stora Karlsö - en presentation, Karlsö Jagt- och Djurskyddsförening.

Hedgren, S. \& Kolehmainen, T. 2000. Häckande fåglar på Stora Karlsö 1998. Länsstyrelsen i Gotlands län.

Hedgren, S. \& Kolehmainen, T. 2006. Häckande fåglar på Stora Karlsö 2005. Länsstyrelsen i Gotlands län.

Hentati-Sundberg, J., Österblom, H., Kadin, M., Jansson, Å. \& Olsson, O. 2011. The Karlsö murre lab methodology can stimulate innovative seabird research. Marine Ornithology 40: 11-16.

Hentati-Sundberg, J., Hjelm, J., Boonstra, W.J. \& Österblom, H. 2015. Management Forcing Increased Specialization in a Fishery System. Ecosystems 18: 45-61. doi:10.1007/ s10021-014-9811-3.

Hentati-Sundberg, J. \& Olsson, O. 2016. Amateur photographs reveal population history of a colonial seabird. Current Biology 26: 226-228.

Hermansson, C. \& Wizén, O. 2014. Fåglarna på Stora Karlsö 2013. Samt jämförelser med inventeringarna gjorda 198485, 1998 och 2005. Rapporter om natur och miljö nr 2014:8. Länsstryrelsen Gotlands län

Herrmann, C., Rintala, J., Lehikoinen, A., Pedersen, I.K., Hario, M., Kadin, M. \& Korpinen, S. 2013. Abundance of waterbirds in the breeding season. HELCOM Core Indicator of Biodiversity.

ICES. 2013. OSPAR request on an update of the ecological quality objective (EcoQO) on seabird population trends. 1.5.6.9.

Kadin, M., Österblom, H., Hentati-Sundberg, J., \& Olsson, O. (2012). Contrasting effects of food quality and quantity on a marine top predator. Marine Ecology Progress Series, 444: 239-249.

Kadin, M., Olsson, O., Hentati-Sundberg, J., Ehrning, E. W., Blenckner, T. 2016. Common Guillemot Uria aalge parents adjust provisioning rates to compensate for low food quality. Ibis 158: 167-178.
Lif, M., Hjernquist, M. \& Olsson, O. 2005. Long-term population trends in the Lesser Black-backed Gull Larus $\mathrm{f}$. fuscus at Stora Karlsö and Lilla Karlsö, and initial results on breeding success. Ornis Svecica 105: 105-112.

Lyngs, P. 2001. Diet of Razorbill Alca torda chicks on Græsholmen, central Baltic Sea. Dansk Ornitologisk Forenings Tidsskrift 95: 69-74.

Lyngs, P. \& Durinck, J. 1998. Diet of Guillemots Uria aalge in the central Baltic Sea. Dansk Ornitologisk Forenings Tidsskrift 92: 197-200.

Meade, J., Hatchwell, B.J., Blanchard, J.L., \& Birkhead, T.R. 2013. The population increase of common guillemots Uria aalge on Skomer Island is explained by intrinsic demographic properties. Journal of Avian Biology 44: 055-061.

Olsson, O., Nilsson, T. \& Fransson, T. 2000. Long-term study of mortality in the common guillemot in the Baltic Sea. Swedish Environmental Protection Agency Report.

Ottosson, U., Ottvall, R., Elmberg, J., Green, M., Gustafsson, R., Haas, F., Holmqvist, N., Lindström, A., Nilsson, L., Svensson, M., Svensson, S. \& Tjernberg, M. 2012. Fåglarna i Sverige - antal och förekomst. SOF - Halmstad. Ottvall, R., Edenius, L., Elmberg, J., Engstrom, H., Green, M., Holmqvist, N., Lindström, Å., Tjernberg, M. \& Part, T. 2009. Population trends for Swedish breeding birds. Ornis Svecica 19: 117-192.

Parsons, M., Mitchell, I., Butler, A., Ratcliffe, N., Frederiksen, M., Foster, S. \& Reid, J.B. 2008. Seabirds as indicators of the marine environment. ICES J. Marine Science 65: 1520-1526. doi:10.1093/icesjms/fsn 155

Schönberg Alm, D. 2007. Feeding behaviour in two sympatrically living Larus gulls in areas with and without an elevated adult mortality. Degree project thesis, Department of Systems Ecology, Stockholm University, Sweden.

Österblom, H., Fransson, T. \& Olsson, O. 2002. Bycatches of common guillemot (Uria aalge) in the Baltic Sea gillnet fishery. Biological Conservation 105: 309-319. doi:10.1016/S0006-3207(01)00211-7.

\section{Sammanfattning}

Stora Karlsö har de enskilt största havsfågelkolonierna i Östersjön. Det har dock saknats uppdaterade siffror på antalet häckande fåglar och trender över tid. Under häckningssäsongen 2014 genomförde vi en heltäckande kartläggning av sillgrisslorna på Stora Karlsö och uppskattar antalet häckande par detta år till 15 700. Vi har kartlagt samtliga häckningsplatser på ön och räknat, direkt eller indirekt, alla häckande par. Dokumentationen av denna räkning kan tjäna som underlag för detaljerade jämförelser i framtiden. En jämförelse med tidigare studier samt fotografisk dokumentation av kolonin visar att antalet sillgrisslor nästan har tredubblats sedan 1970-talet, och att ökningen eskalerat under de senaste 11 åren, då ökningen i genomsnitt har varit $5,1 \%$ per år. Sillgrisslornas expansion har delvis skett genom att häckningsbestånden på befintliga hyllor har förtätats, dels genom en expansion till nya områden, inte minst i blockterräng på strän- 
der. År 2014 häckade omkring 20\% av beståndet på stränder. Vår uppskattning av antalet sillgrisslor på Stora Karlsö tyder på att ön idag hyser väl över hälften, kanske upp till 70\%, av alla Östersjöns sillgrisslor. Vi räknade under säsongerna 2015-2016 till 24600 individer av vuxna tordmular och uppskattar därför antalet häckande par till maximalt 12 300. Siffran bygger på räkning av samtliga tordmular som låg på vattnet, cirka två veckor före äggläggningen, utanför de olika delkolonierna runt Stora Karlsö. Ökningen av tordmular har varit ännu kraftigare än för sillgrisslor, i genomsnitt 5,6\% årligen för hela perioden från 1973 fram till 2015. Vi uppskattar därmed att Stora Karlsö hyser upp till $30 \%$ av Östersjöns tordmulebestånd. Vi rapporterar också antal och trender för silltrut och gråtrut på Stora Karlsö. Båda arterna har minskat i antal de senaste tolv åren (2005-2016); 5,0\% årligen för silltrut och 6,2\% för gråtrut. Dessa arter är mer utspridda på olika lokaler i Östersjön och Stora Karlsö hyser endast några procent av den svenska Östersjöpopulationen. Sammanfattningsvis är Stora Karlsö en betydande häckningslokal i Östersjön för de båda alkarterna, och ön bör därför utgöra en viktig del i den nationella och internationella havsfågelövervakningen. 
Appendix 1. Supplementary data to Olsson, O. \& Hentati-Sundberg, J. 2017.

Population trends and status of four seabird species (Uria aalge, Alca torda, Larus fuscus, Larus argentatus) at Stora Karlsö in the Baltic Sea. Ornis Svecica 27(3-4).

This Appendix includes the raw data for the counting of Common Guillemots Uria aalge at the Stora Karlsö colony in 2014, including geo-coordinates for the counting spots and the number of breeding pairs in each ledge. The spatial references are in three hierarchical levels. The highest level is the "counting spots", which are listed with their spatial coordinates in Table S1. There were in total 35 counting spots, not including the areas that were invisible from land and thus counted from the sea. For each counting spot, we took one or more photographs. The photo ID, each linked to a counting spot, are also listed in table S1. Appendix 2 shows all the photos with the ledges indicated, in total 70 photographs. On each photograph, there was one or more breeding ledges, in total 184 in the entire colony. Because some of the breeding sites were consealed in caves, theses were not possible to count but instead estimated with an indirect method (see manuscript).

This appendix is also available on line at https// doi.org/10.5878/002919.

Table S1. All breeding ledges with indications on their respective photo ID and counting spot (including coordinates), and the number of breeding birds. For ledges indicated and counted on sea-photos, no coordinates are given but the location of the breeding ledges should be possible to identify in the field in the future anyway. Note also that some ledges are depicted on additional photos than the one indicated in the table. The pair values given in this table for 19 ledges at Västberget (marked with "Chicks" in the Comment column) were not used in the final estimatimation; instead we used counts of fledging chicks.

\begin{tabular}{|c|c|c|c|c|c|c|c|c|c|c|}
\hline Date & MainArea & SubArea & $\begin{array}{l}\text { Counting } \\
\text { Spot }\end{array}$ & Lat & Long & PhotoID & $\begin{array}{l}\text { Ledge } \\
\text { ID }\end{array}$ & $\begin{array}{l}\text { Ledge } \\
\text { Type }\end{array}$ & $\begin{array}{r}\text { Estimate } \\
\text { pairs }\end{array}$ & Comment \\
\hline 2014-05-22 & Hassli & Hassli strand & HS A & 57.2924 & 17.9786 & HS A1 & HS1 & Beach & 20 & \\
\hline 2014-05-22 & Hassli & Hassli strand & HS A & 57.2924 & 17.9786 & HS A1 & HS2 & Beach & 5 & \\
\hline 2014-05-22 & Hassli & Hassli strand & HS A & 57.2924 & 17.9786 & HS A1 & HS3 & Beach & 0 & \\
\hline 2014-05-22 & Hassli & Hassli strand & HS B & 57.2925 & 17.9801 & HS A1 & HS4 & Beach & 10 & \\
\hline 2014-05-22 & Hassli & Hassli strand & HS C & 57.2921 & 17.9827 & HS C1 & HS5 & Beach & 10 & \\
\hline 2014-05-22 & Hassli & Hassli strand & HS C & 57.2921 & 17.9827 & HS C1 & HS6 & Beach & 7 & \\
\hline 2014-05-22 & Hassli & Hassli hyllor & HS D & 57.292 & 17.9828 & HS D1 & HS7 & Ledge & 10 & \\
\hline 2014-05-22 & Hassli & Hassli strand & HS E & 57.2909 & 17.9837 & HS E1 & HS8 & Beach & 20 & \\
\hline 2014-05-22 & Hassli & Hassli strand & HS G & 57.2896 & 17.9848 & HS G1 & HS9 & Beach & 10 & \\
\hline 2014-05-22 & Hassli & Hassli hyllor & HS H & 57.2893 & 17.9855 & HS H1 & HS10 & Ledge & 10 & \\
\hline 2014-05-20 & Stornasar & Lerberget hyllor & SN A & 57.2859 & 17.9575 & SN A1 & SN1 & Ledge & 25 & \\
\hline 2014-05-20 & Stornasar & Lerberget hyllor & SN A & 57.2859 & 17.9575 & SN A1 & SN2 & Ledge & 32 & \\
\hline 2014-05-20 & Stornasar & Lerberget hyllor & SN A & 57.2859 & 17.9575 & SN A1 & SN3 & Ledge & 0 & \\
\hline 2014-05-20 & Stornasar & Lerberget hyllor & SN A & 57.2859 & 17.9575 & SN A1 & SN4 & Ledge & 30 & \\
\hline 2014-05-20 & Stornasar & Lerberget hyllor & SN A & 57.2859 & 17.9575 & SN A1 & SN5 & Ledge & 30 & \\
\hline 2014-05-20 & Stornasar & Lerberget hyllor & SN A & 57.2859 & 17.9575 & SN A1 & SN6 & Ledge & 50 & \\
\hline 2014-05-20 & Stornasar & Lerberget hyllor & SN A & 57.2859 & 17.9575 & SN A1 & SN7 & Ledge & 20 & \\
\hline 2014-05-20 & Stornasar & Stornasar strand & SN B & 57.2846 & 17.9568 & SN B1 & SN13 & Beach & 15 & \\
\hline 2014-05-20 & Stornasar & Stornasar strand & SN D & 57.2847 & 17.957 & SN D1 & SN8 & Beach & 25 & \\
\hline $2014-05-20$ & Stornasar & Stornasar strand & SN D & 57.2847 & 17.957 & SN D1 & SN9 & Beach & 105 & \\
\hline 2014-05-20 & Stornasar & Stornasar strand & SN D & 57.2847 & 17.957 & SN D1 & SN10 & Beach & 12 & \\
\hline 2014-05-20 & Stornasar & Stornasar strand & SN D & 57.2847 & 17.957 & SN D1 & SN11 & Beach & 30 & \\
\hline 2014-05-20 & Stornasar & Stornasar strand & SN D & 57.2847 & 17.957 & SN D1 & SN12 & Beach & 82 & \\
\hline 2014-05-20 & Stornasar & Stornasar hyllor & SNE & 57.2846 & 17.9569 & SN E1 & SN15 & Ledge & 150 & \\
\hline 2014-05-20 & Stornasar & Stornasar hyllor & SN E & 57.2846 & 17.9569 & SN E1 & SN16 & Ledge & 195 & \\
\hline 2014-05-20 & Stornasar & Stornasar hyllor & SNE & 57.2846 & 17.9569 & SN E1 & SN17 & Ledge & 140 & \\
\hline 2014-05-20 & Stornasar & Stornasar hyllor & SNE & 57.2846 & 17.9569 & SN E1 & SN18 & Ledge & 140 & \\
\hline 2014-05-20 & Svarthallar & Svarthallar & SH H & 57.2813 & 17.9857 & SH H1 & SH15 & Beach & 35 & \\
\hline 2014-05-20 & Svarthallar & Svarthallar & SH I & 57.2817 & 17.9862 & SH I1 & SH16 & Beach & 240 & \\
\hline 2014-05-20 & Svarthallar & Svarthallar & SH J & 57.2817 & 17.9865 & SH J1 & SH17 & Beach & 100 & \\
\hline
\end{tabular}




\begin{tabular}{|c|c|c|c|c|c|c|c|c|c|c|}
\hline Date & MainArea & SubArea & $\begin{array}{l}\text { Counting } \\
\text { Spot }\end{array}$ & Lat & Long & PhotoID & $\begin{array}{l}\text { Ledge } \\
\text { ID }\end{array}$ & $\begin{array}{l}\text { Ledge } \\
\text { Type }\end{array}$ & $\begin{array}{r}\text { Estimate } \\
\text { pairs }\end{array}$ & Comment \\
\hline 2014-05-20 & Stornasar & Stornasar hyllor & SNE & 57.2846 & 17.9569 & SN E1 & SN19 & Ledge & 90 & \\
\hline 2014-05-20 & Stornasar & Stornasar hyllor & SNE & 57.2846 & 17.9569 & SN E1 & SN20 & Ledge & 210 & \\
\hline 2014-05-20 & Stornasar & Stornasar hyllor & SN E & 57.2846 & 17.9569 & SN E1 & SN21 & Ledge & 250 & \\
\hline 2014-05-20 & Stornasar & Stornasar hyllor & SNE & 57.2846 & 17.9569 & SN E1 & SN22 & Ledge & 175 & \\
\hline $2014-05-20$ & Stornasar & Stornasar hyllor & SNE & 57.2846 & 17.9569 & SN E1 & SN23 & Ledge & 70 & \\
\hline 2014-05-20 & Stornasar & Stornasar hyllor & SN E & 57.2846 & 17.9569 & SN E1 & $\mathrm{SN} 24$ & Ledge & 50 & \\
\hline 2014-05-20 & Stornasar & Stornasar hyllor & SN E & 57.2846 & 17.9569 & SN E1 & SN25 & Ledge & 42 & \\
\hline 2014-05-20 & Stornasar & Stornasar hyllor & SNE & 57.2846 & 17.9569 & SN E1 & SN26 & Ledge & 52 & \\
\hline 2014-05-20 & Stornasar & Stornasar strand & SNE & 57.2846 & 17.9569 & SN E2 & SN29 & Beach & 120 & \\
\hline 2014-05-20 & Stornasar & Stornasar strand & SN E & 57.2846 & 17.9569 & SN E2 & SN30 & Beach & 70 & \\
\hline 2014-05-21 & Stornasar & Stornasar strand & SNE & 57.2846 & 17.9569 & SN E3 & SN31 & Beach & 100 & \\
\hline 2014-05-21 & Stornasar & Stornasar hyllor & SN F & 57.2841 & 17.9568 & SN F1 & SN14 & Ledge & 25 & \\
\hline 2014-05-21 & Stornasar & Stornasar hyllor & SN F & 57.2841 & 17.9568 & SN F2 & SN32 & Ledge & 15 & \\
\hline 2014-05-21 & Stornasar & Stornasar hyllor & SN F & 57.2841 & 17.9568 & SN F3 & SN33 & Ledge & 90 & \\
\hline 2014-05-21 & Stornasar & Stornasar hyllor & SN F & 57.2841 & 17.9568 & SN F3 & SN34 & Ledge & 20 & \\
\hline 2014-05-21 & Stornasar & Stornasar hyllor & SN G & 57.284 & 17.9566 & SN G1 & SN27 & Ledge & 55 & \\
\hline 2014-05-21 & Stornasar & Stornasar hyllor & SN H & 57.2838 & 17.9565 & SN H1 & SN35 & Ledge & 40 & \\
\hline 2014-05-21 & Stornasar & Stornasar hyllor & SN H & 57.2838 & 17.9565 & SN H1 & SN36 & Ledge & 20 & \\
\hline 2014-05-21 & Stornasar & Stornasar hyllor & SN H & 57.2838 & 17.9565 & SN H2 & SN37 & Ledge & 80 & \\
\hline 2014-05-21 & Stornasar & Stornasar hyllor & SN H & 57.2838 & 17.9565 & SN H3 & SN38 & Ledge & 13 & \\
\hline 2014-05-21 & Stornasar & Stornasar strand & SN H & 57.2838 & 17.9565 & SN H4 & SN28 & Beach & 250 & \\
\hline 2014-05-21 & Stornasar & Stornasar strand & SN H & 57.2838 & 17.9565 & SN H4 & SN39 & Beach & 100 & \\
\hline 2014-05-21 & Stornasar & Stornasar strand & SN H & 57.2838 & 17.9565 & SN H4 & SN40 & Beach & 70 & \\
\hline 2014-05-21 & Franska bukten & Franska bukten hyllor & SN I & 57.2831 & 17.9573 & SN I1 & SN41 & Ledge & 10 & \\
\hline 2014-05-21 & Franska bukten & Franska bukten hyllor & SN I & 57.2831 & 17.9573 & SN I1 & SN42 & Ledge & 7 & \\
\hline 2014-05-21 & Franska bukten & Franska bukten hyllor & SN I & 57.2831 & 17.9573 & SN I1 & SN43 & Ledge & 10 & \\
\hline 2014-05-21 & Franska bukten & Franska bukten hyllor & SN I & 57.2831 & 17.9573 & SN I3 & SN46 & Ledge & 15 & \\
\hline 2014-05-21 & Franska bukten & Franska bukten hyllor & SN I & 57.2831 & 17.9573 & SN I4 & SN47 & Ledge & 30 & \\
\hline 2014-05-21 & Franska bukten & Franska bukten hyllor & SN I & 57.2831 & 17.9573 & SN I4 & SN48 & Ledge & 80 & \\
\hline 2014-06-30 & Franska bukten & Franska bukten strand & SN L & 57.2835 & 17.9564 & SN L1 & SN55 & Beach & 270 & \\
\hline 2014-05-20 & Stornasar & Stornasar hyllor & SN Vatten 1 & & & SN Vatten 1 & SN56 & Ledge & 20 & \\
\hline 2014-05-20 & Stornasar & Stornasar hyllor & SN Vatten 1 & & & SN Vatten 1 & SN57 & Ledge & 27 & \\
\hline 2014-05-20 & Stornasar & Stornasar hyllor & SN Vatten 1 & & & SN Vatten 1 & SN58 & Ledge & 45 & \\
\hline 2014-05-21 & Franska bukten & Franska bukten hyllor & SN Vatten 2 & & & SN Vatten 2 & SN44 & Ledge & 1 & \\
\hline 2014-05-21 & Franska bukten & Franska bukten hyllor & SN Vatten 2 & & & SN Vatten 2 & SN45 & Ledge & 32 & \\
\hline 2014-05-21 & Franska bukten & Franska bukten hyllor & SN Vatten 2 & & & SN Vatten2 & SN49 & Ledge & 17 & \\
\hline 2014-05-21 & Franska bukten & Franska bukten hyllor & SN Vatten 2 & & & SN Vatten 2 & SN50 & Ledge & 50 & \\
\hline 2014-05-20 & Franska bukten & Franska bukten hyllor & SN Vatten 2 & & & SN Vatten2 & SN51 & Ledge & 200 & \\
\hline 2014-05-20 & Franska bukten & Franska bukten hyllor & SN Vatten 3 & & & SN Vatten 3 & SN52 & Ledge & 47 & \\
\hline 2014-05-20 & Franska bukten & Franska bukten strand & SN Vatten 3 & & & SN Vatten 3 & SN53 & Beach & 35 & \\
\hline 2014-05-20 & Franska bukten & Franska bukten strand & SN Vatten 3 & & & SN Vatten3 & SN54 & Beach & 15 & \\
\hline 2014-05-20 & Svarthallar & Svarthallar & SH A & 57.2801 & 17.9829 & SH A1 & SH1 & Beach & 80 & \\
\hline 2014-05-20 & Svarthallar & Svarthallar & SH A & 57.2801 & 17.9829 & SH A2 & $\mathrm{SH} 2$ & Beach & 25 & \\
\hline 2014-05-20 & Svarthallar & Svarthallar & SH A & 57.2801 & 17.9829 & SH A3 & SH3 & Beach & 350 & \\
\hline 2014-05-20 & Svarthallar & Svarthallar & SH A & 57.2801 & 17.9829 & SH A3 & SH4 & Beach & 310 & \\
\hline 2014-05-20 & Svarthallar & Svarthallar & SH B & 57.2805 & 17.9828 & SH B1 & SH5 & Beach & 60 & \\
\hline 2014-05-20 & Svarthallar & Svarthallar & SH E & 57.2809 & 17.9846 & SH E1 & SH6 & Beach & 25 & \\
\hline 2014-05-20 & Svarthallar & Svarthallar & SHE & 57.2809 & 17.9846 & SH E1 & SH7 & Beach & 15 & \\
\hline 2014-05-20 & Svarthallar & Svarthallar & SHE & 57.2809 & 17.9846 & SH E1 & SH8 & Beach & 20 & \\
\hline 2014-05-20 & Svarthallar & Svarthallar & SHE & 57.2809 & 17.9846 & SH E2 & SH9 & Beach & 5 & \\
\hline 2014-05-20 & Svarthallar & Svarthallar & SH E & 57.2809 & 17.9846 & SH E3 & SH10 & Beach & 30 & \\
\hline 2014-05-20 & Svarthallar & Svarthallar & SH F & 57.2811 & 17.985 & SH F1 & SH11 & Beach & 15 & \\
\hline 2014-05-20 & Svarthallar & Svarthallar & SHF & 57.2811 & 17.985 & SH F1 & SH12 & Beach & 40 & \\
\hline $2014-05-20$ & Svarthallar & Svarthallar & SH F & 57.2811 & 17.985 & SH F1 & SH13 & Beach & 20 & \\
\hline $2014-05-20$ & Svarthallar & Svarthallar & SH G & 57.2812 & 17.9854 & SH G1 & SH14 & Beach & 90 & \\
\hline
\end{tabular}




\begin{tabular}{|c|c|c|c|c|c|c|c|c|c|c|}
\hline Date & MainArea & SubArea & $\begin{array}{l}\text { Counting } \\
\text { Spot }\end{array}$ & Lat & Long & PhotoID & $\begin{array}{l}\text { Ledge } \\
\text { ID }\end{array}$ & $\begin{array}{l}\text { Ledge } \\
\text { Type }\end{array}$ & $\begin{array}{r}\text { Estimate } \\
\text { pairs }\end{array}$ & Comment \\
\hline $2014-05-20$ & Svarthallar & Svarthallar & SH J & 57.2817 & 17.9865 & $\mathrm{SH} \mathbf{J} 2$ & SH18 & Beach & 40 & \\
\hline 2014-05-20 & Svarthallar & Svarthallar & SH J & 57.2817 & 17.9865 & $\mathrm{SH} \mathbf{J} 2$ & SH19 & Beach & 10 & \\
\hline 2014-05-20 & Svarthallar & Svarthallar & SH J & 57.2817 & 17.9865 & $\mathrm{SH} \mathrm{J} 2$ & SH20 & Beach & 60 & \\
\hline 2014-05-20 & Svarthallar & Svarthallar & SH K & 57.2821 & 17.9869 & SH K2 & SH21 & Beach & 70 & \\
\hline 2014-05-20 & Svarthallar & Svarthallar & SH K & 57.2821 & 17.9869 & SH K2 & SH22 & Beach & 70 & \\
\hline 2014-05-20 & Svarthallar & Svarthallar & SH L & 57.2821 & 17.9875 & SH L1 & SH23 & Beach & 55 & \\
\hline 2014-05-20 & Svarthallar & Svarthallar & SH L & 57.2821 & 17.9875 & SH L2 & SH24 & Beach & 80 & \\
\hline 2014-05-20 & Svarthallar & Svarthallar & SH L & 57.2821 & 17.9875 & SH L3 & SH25 & Beach & 5 & \\
\hline 2014-05-20 & Svarthallar & Svarthallar & SH L & 57.2821 & 17.9875 & SH L3 & SH26 & Beach & 5 & \\
\hline 2014-05-20 & Svarthallar & Svarthallar & SH L & 57.2821 & 17.9875 & SH L4 & SH27 & Beach & 15 & \\
\hline 2014-05-20 & Svarthallar & Svarthallar & SH L & 57.2821 & 17.9875 & SH L4 & SH28 & Beach & 40 & \\
\hline 2014-05-20 & Svarthallar & Svarthallar & SH L & 57.2821 & 17.9875 & SH L5 & SH29 & Beach & 10 & \\
\hline 2014-05-20 & Svarthallar & Svarthallar & SH M & 57.2827 & 17.9883 & SH M1 & SH30 & Beach & 35 & \\
\hline 2014-05-20 & Svarthallar & Svarthallar & SH M & 57.2827 & 17.9883 & SH M1 & SH31 & Beach & 15 & \\
\hline 2014-05-20 & Svarthallar & Svarthallar & SH N & 57.2833 & 17.9892 & SH N1 & SH32 & Beach & 25 & \\
\hline 2014-05-22 & Vasterberget & $\begin{array}{l}\text { Vasterberget hyllor } \\
\text { Lushålet }\end{array}$ & VB B & 57.289 & 17.958 & VB B1 & $\mathrm{V} 1$ & Ledge & 16 & Chicks \\
\hline 2014-05-22 & Vasterberget & $\begin{array}{l}\text { Vasterberget hyllor } \\
\text { Lushålet }\end{array}$ & VB B & 57.289 & 17.958 & VB B1 & $\mathrm{V} 2$ & Ledge & 160 & Chicks \\
\hline 2014-05-22 & Vasterberget & $\begin{array}{l}\text { Vasterberget hyllor } \\
\text { Lushålet }\end{array}$ & VB B & 57.289 & 17.958 & VB B1 & V3 & Ledge & 5 & Chicks \\
\hline 2014-05-22 & Vasterberget & $\begin{array}{l}\text { Vasterberget hyllor } \\
\text { Lushålet }\end{array}$ & VB B & 57.289 & 17.958 & VB B1 & V4 & Ledge & 28 & Chicks \\
\hline 2014-05-22 & Vasterberget & $\begin{array}{l}\text { Vasterberget hyllor } \\
\text { Lushålet }\end{array}$ & VB B & 57.289 & 17.958 & VB B1 & V5 & Ledge & 65 & Chicks \\
\hline 2014-05-22 & Vasterberget & $\begin{array}{l}\text { Vasterberget hyllor } \\
\text { Lushålet }\end{array}$ & VB B & 57.289 & 17.958 & VB B1 & V6 & Ledge & 40 & Chicks \\
\hline 2014-05-22 & Vasterberget & $\begin{array}{l}\text { Vasterberget hyllor } \\
\text { Lushålet }\end{array}$ & VB C & 57.2894 & 17.9579 & VB C1 & V7 & Ledge & 54 & Chicks \\
\hline 2014-05-22 & Vasterberget & $\begin{array}{l}\text { Vasterberget hyllor } \\
\text { Lushålet }\end{array}$ & VB C & 57.2894 & 17.9579 & VB C1 & V8 & Ledge & 26 & Chicks \\
\hline 2014-05-22 & Vasterberget & $\begin{array}{l}\text { Vasterberget hyllor } \\
\text { Lushålet }\end{array}$ & VB C & 57.2894 & 17.9579 & VB C1 & V9 & Ledge & 22 & Chicks \\
\hline 2014-05-22 & Vasterberget & $\begin{array}{l}\text { Vasterberget hyllor } \\
\text { Lushålet }\end{array}$ & VB C & 57.2894 & 17.9579 & VB C2 & V10 & Ledge & 30 & Chicks \\
\hline 2014-05-22 & Vasterberget & \multicolumn{2}{|c|}{$\begin{array}{l}\text { Lushälet } \\
\text { Vasterberget hyllor RöretVB D }\end{array}$} & 57.2896 & 17.9579 & VB D1 & V12 & Ledge & 30 & Chicks \\
\hline 2014-05-22 & Vasterberget & \multicolumn{2}{|c|}{ Vasterberget hyllor RöretVB D } & 57.2896 & 17.9579 & VB D1 & V13 & Ledge & 39 & Chicks \\
\hline 2014-05-22 & Vasterberget & \multicolumn{2}{|c|}{ Vasterberget hyllor RöretVB D } & 57.2896 & 17.9579 & VB D1 & V14 & Ledge & 17 & Chicks \\
\hline 2014-05-22 & Vasterberget & \multicolumn{2}{|c|}{ Vasterberget hyllor RöretVB E } & 57.2898 & 17.9581 & VB E1 & V15 & Ledge & 275 & Chicks \\
\hline 2014-05-22 & Vasterberget & \multicolumn{2}{|c|}{ Vasterberget hyllor RöretVB E } & 57.2898 & 17.9581 & VB E1 & V16 & Ledge & 195 & Chicks \\
\hline 2014-05-22 & Vasterberget & \multicolumn{2}{|c|}{ Vasterberget hyllor RöretVB E } & 57.2898 & 17.9581 & VB E1 & V17 & Ledge & 60 & Chicks \\
\hline 2014-05-22 & Vasterberget & \multicolumn{2}{|c|}{ Vasterberget hyllor RöretVB E } & 57.2898 & 17.9581 & VB E1 & V18 & Ledge & 54 & Chicks \\
\hline 2014-05-22 & Vasterberget & \multicolumn{2}{|c|}{ Vasterberget hyllor RöretVB E } & 57.2898 & 17.9581 & VB E1 & V19 & Ledge & 180 & Chicks \\
\hline 2014-05-22 & Vasterberget & \multicolumn{2}{|c|}{ Vasterberget hyllor RöretVB E } & 57.2898 & 17.9581 & VB E1 & V20 & Ledge & 95 & Chicks \\
\hline 2014-05-22 & Vasterberget & $\begin{array}{l}\text { Vasterberget hyllor } \\
\text { Rindhålet }\end{array}$ & VB F & 57.2902 & 17.9583 & VB F1 & $\mathrm{V} 21$ & Ledge & 267 & \\
\hline 2014-05-22 & Vasterberget & $\begin{array}{l}\text { Vasterberget hyllor } \\
\text { Rindhålet }\end{array}$ & VB F & 57.2902 & 17.9583 & VB F1 & V22 & Ledge & 217 & \\
\hline 2014-05-22 & Vasterberget & $\begin{array}{l}\text { Vasterberget hyllor } \\
\text { Rindhålet }\end{array}$ & VB F & 57.2902 & 17.9583 & VB F1 & V24 & Ledge & 350 & \\
\hline 2014-06-11 & Vasterberget & $\begin{array}{l}\text { Vasterberget hyllor } \\
\text { Korphålet }\end{array}$ & VB H & 57.2906 & 17.9588 & VB H1 & V62 & Ledge & 40 & \\
\hline 2014-06-11 & Vasterberget & $\begin{array}{l}\text { Vasterberget hyllor } \\
\text { Korphålet }\end{array}$ & VB H & 57.2906 & 17.9588 & VB H1 & V63 & Ledge & 590 & \\
\hline 2014-06-11 & Vasterberget & $\begin{array}{l}\text { Vasterberget hyllor } \\
\text { Korphålet }\end{array}$ & VB H & 57.2906 & 17.9588 & VB H1 & V64 & Ledge & 230 & \\
\hline 2014-06-11 & Vasterberget & $\begin{array}{l}\text { Vasterberget hyllor } \\
\text { Korphålet }\end{array}$ & VB H & 57.2906 & 17.9588 & VB H1 & V65 & Ledge & 145 & \\
\hline 2014-06-11 & Vasterberget & $\begin{array}{l}\text { Vasterberget hyllor } \\
\text { Korphålet }\end{array}$ & VB H & 57.2906 & 17.9588 & VB H1 & V66 & Ledge & 180 & \\
\hline 2014-06-11 & Vasterberget & $\begin{array}{l}\text { Vasterberget hyllor } \\
\text { Rindhålet }\end{array}$ & VB I & 57.2902 & 17.9585 & VB I1 & V67 & Ledge & 180 & \\
\hline 2014-06-11 & Vasterberget & $\begin{array}{l}\text { Vasterberget hyllor } \\
\text { Rindhålet }\end{array}$ & VB I & 57.2902 & 17.9585 & VB I1 & V68 & Ledge & 320 & \\
\hline 2014-06-11 & Vasterberget & $\begin{array}{l}\text { Vasterberget hyllor } \\
\text { Rindhålet }\end{array}$ & VB I & 57.2902 & 17.9585 & VB I1 & V69 & Ledge & 210 & \\
\hline 2014-06-11 & Vasterberget & $\begin{array}{l}\text { Vasterberget hyllor } \\
\text { Rindhålet }\end{array}$ & VB I & 57.2902 & 17.9585 & VB I1 & V70 & Ledge & 110 & \\
\hline 2014-06-11 & Vasterberget & $\begin{array}{l}\text { Vasterberget hyllor } \\
\text { Rindhålet }\end{array}$ & VB I & 57.2902 & 17.9585 & VB I1 & V71 & Ledge & 110 & \\
\hline 2014-06-11 & Vasterberget & $\begin{array}{l}\text { Vasterberget hyllor } \\
\text { Rindhålet }\end{array}$ & VB I & 57.2902 & 17.9585 & VB I1 & V72 & Ledge & 140 & \\
\hline 2014-06-11 & Vasterberget & $\begin{array}{l}\text { Vasterberget hyllor } \\
\text { Rindhålet }\end{array}$ & VB I & 57.2902 & 17.9585 & VB I1 & V73 & Ledge & 25 & \\
\hline
\end{tabular}




\begin{tabular}{|c|c|c|c|c|c|c|c|c|c|c|}
\hline Date & MainArea & SubArea & $\begin{array}{l}\text { Counting } \\
\text { Spot }\end{array}$ & Lat & Long & PhotoID & $\begin{array}{l}\text { Ledge } \\
\text { ID }\end{array}$ & $\begin{array}{l}\text { Ledge } \\
\text { Type }\end{array}$ & $\begin{array}{r}\text { Estimate } \\
\text { pairs }\end{array}$ & Comment \\
\hline $2014-05-20$ & Vasterberget & $\begin{array}{l}\text { Vasterberget hyllor } \\
\text { Lushålet }\end{array}$ & VB Vatten1 & & & VB Vatten1 & V46 & Ledge & 25 & \\
\hline 2014-05-20 & Vasterberget & $\begin{array}{l}\text { Vasterberget hyllor } \\
\text { Lushålet }\end{array}$ & VB Vatten1 & & & VB Vatten1 & V47 & Ledge & 10 & \\
\hline 2014-05-20 & Vasterberget & $\begin{array}{l}\text { Vasterberget hyllor } \\
\text { Lushålet }\end{array}$ & VB Vatten1 & & & VB Vatten1 & V48 & Ledge & 0 & \\
\hline 2014-05-20 & Vasterberget & $\begin{array}{l}\text { Vasterberget hyllor } \\
\text { Lushålet }\end{array}$ & VB Vatten1 & & & VB Vatten 1 & V49 & Ledge & 5 & \\
\hline 2014-05-20 & Vasterberget & $\begin{array}{l}\text { Vasterberget hyllor } \\
\text { Lushålet }\end{array}$ & VB Vatten2 & & & VB Vatten2 & V42 & Ledge & 50 & \\
\hline 2014-05-20 & Vasterberget & $\begin{array}{l}\text { Vasterberget hyllor } \\
\text { Lushålet }\end{array}$ & VB Vatten2 & & & VB Vatten2 & V43 & Ledge & 10 & \\
\hline 2014-05-20 & Vasterberget & $\begin{array}{l}\text { Vasterberget hyllor } \\
\text { Lushålet }\end{array}$ & VB Vatten2 & & & VB Vatten2 & V44 & Ledge & 35 & \\
\hline 2014-05-20 & Vasterberget & $\begin{array}{l}\text { Vasterberget hyllor } \\
\text { Lushålet }\end{array}$ & VB Vatten2 & & & VB Vatten2 & V45 & Ledge & 80 & \\
\hline 2014-05-22 & Vasterberget & $\begin{array}{l}\text { Vasterberget hyllor } \\
\text { Lushålet }\end{array}$ & VB Vatten3 & & & VB Vatten3 & V11 & Ledge & 7 & \\
\hline 2014-05-20 & Vasterberget & $\begin{array}{l}\text { Vasterberget hyllor } \\
\text { Lushålet }\end{array}$ & VB Vatten3 & & & VB Vatten3 & V36 & Ledge & 80 & \\
\hline 2014-05-20 & Vasterberget & $\begin{array}{l}\text { Vasterberget hyllor } \\
\text { Lushålet }\end{array}$ & VB Vatten3 & & & VB Vatten3 & V37 & Ledge & 200 & \\
\hline 2014-05-20 & Vasterberget & $\begin{array}{l}\text { Vasterberget hyllor } \\
\text { Lushålet }\end{array}$ & VB Vatten3 & & & VB Vatten3 & V38 & Ledge & 150 & \\
\hline 2014-05-20 & Vasterberget & $\begin{array}{l}\text { Vasterberget hyllor } \\
\text { Lushålet }\end{array}$ & VB Vatten3 & & & VB Vatten3 & V39 & Ledge & 125 & \\
\hline 2014-05-20 & Vasterberget & $\begin{array}{l}\text { Vasterberget hyllor } \\
\text { Lushålet }\end{array}$ & VB Vatten3 & & & VB Vatten3 & V40 & Ledge & 425 & \\
\hline 2014-05-20 & Vasterberget & $\begin{array}{l}\text { Vasterberget hyllor } \\
\text { Lushålet }\end{array}$ & VB Vatten3 & & & VB Vatten3 & V41 & Ledge & 45 & \\
\hline 2014-05-22 & Vasterberget & Vasterberget hyllor $\mathrm{R}$ & tVB Vatten4 & & & VB Vatten4 & V31 & Ledge & 87 & \\
\hline 2014-05-22 & Vasterberget & Vasterberget hyllor $\mathrm{K}$ & tVB Vatten4 & & & VB Vatten 4 & V32 & Ledge & 75 & \\
\hline 2014-05-22 & Vasterberget & Vasterberget hyllor $\mathrm{B}$ & tVB Vatten4 & & & VB Vatten4 & V33 & Ledge & 125 & \\
\hline $2014-05-22$ & Vasterberget & Vasterberget hyllor $\mathrm{F}$ & tVB Vatten4 & & & VB Vatten4 & V34 & Ledge & 75 & \\
\hline 2014-05-22 & Vasterberget & Vasterberget hyllor $\mathrm{R}$ & tVB Vatten4 & & & VB Vatten4 & V35 & Ledge & 20 & \\
\hline 2014-05-20 & Vasterberget & Vasterberget hyllor $\mathrm{K}$ & tVB Vatten4 & & & VB Vatten4 & V50 & Ledge & 65 & \\
\hline 2014-05-20 & Vasterberget & Vasterberget hyllor $\mathrm{K}$ & tVB Vatten4 & & & VB Vatten4 & V51 & Ledge & 300 & \\
\hline 2014-05-20 & Vasterberget & Vasterberget hyllor $\mathrm{R}$ & tVB Vatten4 & & & VB Vatten4 & V52 & Ledge & 20 & \\
\hline 2014-05-22 & Vasterberget & $\begin{array}{l}\text { Vasterberget hyllor } \\
\text { Rindhålet }\end{array}$ & VB Vatten5 & & & VB Vatten5 & V27 & Ledge & 40 & \\
\hline 2014-05-22 & Vasterberget & $\begin{array}{l}\text { Vasterberget hyllor } \\
\text { Rindhålet }\end{array}$ & VB Vatten5 & & & VB Vatten 5 & V28 & Ledge & 40 & \\
\hline 2014-05-22 & Vasterberget & $\begin{array}{l}\text { Vasterberget hyllor } \\
\text { Rindhålet }\end{array}$ & VB Vatten5 & & & VB Vatten5 & V29 & Ledge & 4 & \\
\hline 2014-05-22 & Vasterberget & $\begin{array}{l}\text { Vasterberget hyllor } \\
\text { Rindhålet }\end{array}$ & VB Vatten5 & & & VB Vatten5 & V30 & Ledge & 6 & \\
\hline 2014-05-20 & Vasterberget & $\begin{array}{l}\text { Vasterberget hyllor } \\
\text { Rindhålet }\end{array}$ & VB Vatten5 & & & VB Vatten5 & V53 & Ledge & 25 & \\
\hline 2014-05-20 & Vasterberget & $\begin{array}{l}\text { Vasterberget hyllor } \\
\text { Rindhålet }\end{array}$ & VB Vatten5 & & & VB Vatten5 & V54 & Ledge & 50 & \\
\hline 2014-05-20 & Vasterberget & $\begin{array}{l}\text { Vasterberget hyllor } \\
\text { Korphålet }\end{array}$ & VB Vatten5 & & & VB Vatten5 & V57 & Ledge & 160 & \\
\hline 2014-05-20 & Vasterberget & $\begin{array}{l}\text { Vasterberget hyllor } \\
\text { Korphålet }\end{array}$ & VB Vatten6 & & & VB Vatten6 & V58 & Ledge & 180 & \\
\hline 2014-05-20 & Vasterberget & $\begin{array}{l}\text { Vasterberget hyllor } \\
\text { Korphålet }\end{array}$ & VB Vatten6 & & & VB Vatten6 & V59 & Ledge & 15 & \\
\hline 2014-05-22 & Vasterberget & $\begin{array}{l}\text { Vasterberget hyllor } \\
\text { Spangande }\end{array}$ & VB Vatten7 & & & VB Vatten7 & V25 & Ledge & 10 & \\
\hline 2014-05-22 & Vasterberget & $\begin{array}{l}\text { Vasterberget hyllor } \\
\text { Spangande }\end{array}$ & VB Vatten7 & & & VB Vatten7 & V26 & Ledge & 35 & \\
\hline 2014-05-20 & Vasterberget & $\begin{array}{l}\text { Vasterberget hyllor } \\
\text { Spangande }\end{array}$ & VB Vatten7 & & & VB Vatten7 & V60 & Ledge & 30 & \\
\hline 2014-05-20 & Vasterberget & $\begin{array}{l}\text { Vasterberget hyllor } \\
\text { Spangande }\end{array}$ & VB Vatten7 & & & VB Vatten7 & V61 & Ledge & 20 & \\
\hline 2014-05-23 & Vasterberget & Vasterberget strand & VB Strand1 & 57.2908 & 17.9591 & VB Strand1 & VS1 & Beach & 10 & \\
\hline 2014-05-23 & Vasterberget & Vasterberget strand & VB Strand1 & 57.2908 & 17.9591 & VB Strand1 & VS2 & Beach & 10 & \\
\hline 2014-05-23 & Vasterberget & Vasterberget strand & VB Strand1 & 57.2908 & 17.9591 & VB Strand1 & VS3 & Beach & 5 & \\
\hline 2014-05-23 & Vasterberget & Vasterberget strand & VB Strand1 & 57.2908 & 17.9591 & VB Strand1 & VS4 & Beach & 20 & \\
\hline 2014-05-23 & Vasterberget & Vasterberget strand & VB Strand1 & 57.291 & 17.9594 & VB Strand1 & VS5 & Beach & 15 & \\
\hline 2014-05-23 & Vasterberget & Vasterberget strand & VB Strand2 & 57.2912 & 17.9597 & VB Strand2 & VS6 & Beach & 5 & \\
\hline 2014-05-23 & Vasterberget & Vasterberget strand & VB Strand2 & 57.2912 & 17.9597 & VB Strand2 & VS7 & Beach & 5 & \\
\hline 2014-05-23 & Vasterberget & Vasterberget strand & VB Strand3 & 57.2911 & 17.9603 & VB Strand3 & VS8 & Beach & 50 & \\
\hline 2014-05-23 & Vasterberget & Vasterberget strand & VB Strand4 & 57.2911 & 17.9603 & VB Strand4 & VS9 & Beach & 30 & \\
\hline 2014-05-23 & Vasterberget & Vasterberget strand & VB Strand5 & 57.2911 & 17.9603 & VB Strand5 & VS10 & Beach & 5 & \\
\hline 2014-05-23 & Vasterberget & Vasterberget strand & VB Strand6 & 57.2911 & 17.9603 & VB Strand6 & VS11 & Beach & 30 & \\
\hline 2014-05-23 & Vasterberget & Vasterberget strand & VB Strand7 & 57.291 & 17.9607 & VB Strand7 & VS12 & Beach & 30 & \\
\hline
\end{tabular}


Appendix 2. Supplementary data to Olsson, O. \& Hentati-Sundberg, J. 2017. Population trends and status of four seabird species (Uria aalge, Alca torda, Larus fuscus, Larus argentatus) at Stora Karlsö in the Baltic Sea. Ornis Svecica 27(2-4).

This Appendix is also available on line at https://doi.org/10.5878/002919.

The following 70 photographs show all breeding ledges of Common Guillemots Uria aalge at the Stora Karlsö colony in 2014. The photographs and the counting spots, including all ledges and the number of breeding pairs, are listed in Appendix 1, Table S1. Geo-coordinates are also given in Appendix 1, Table S1.
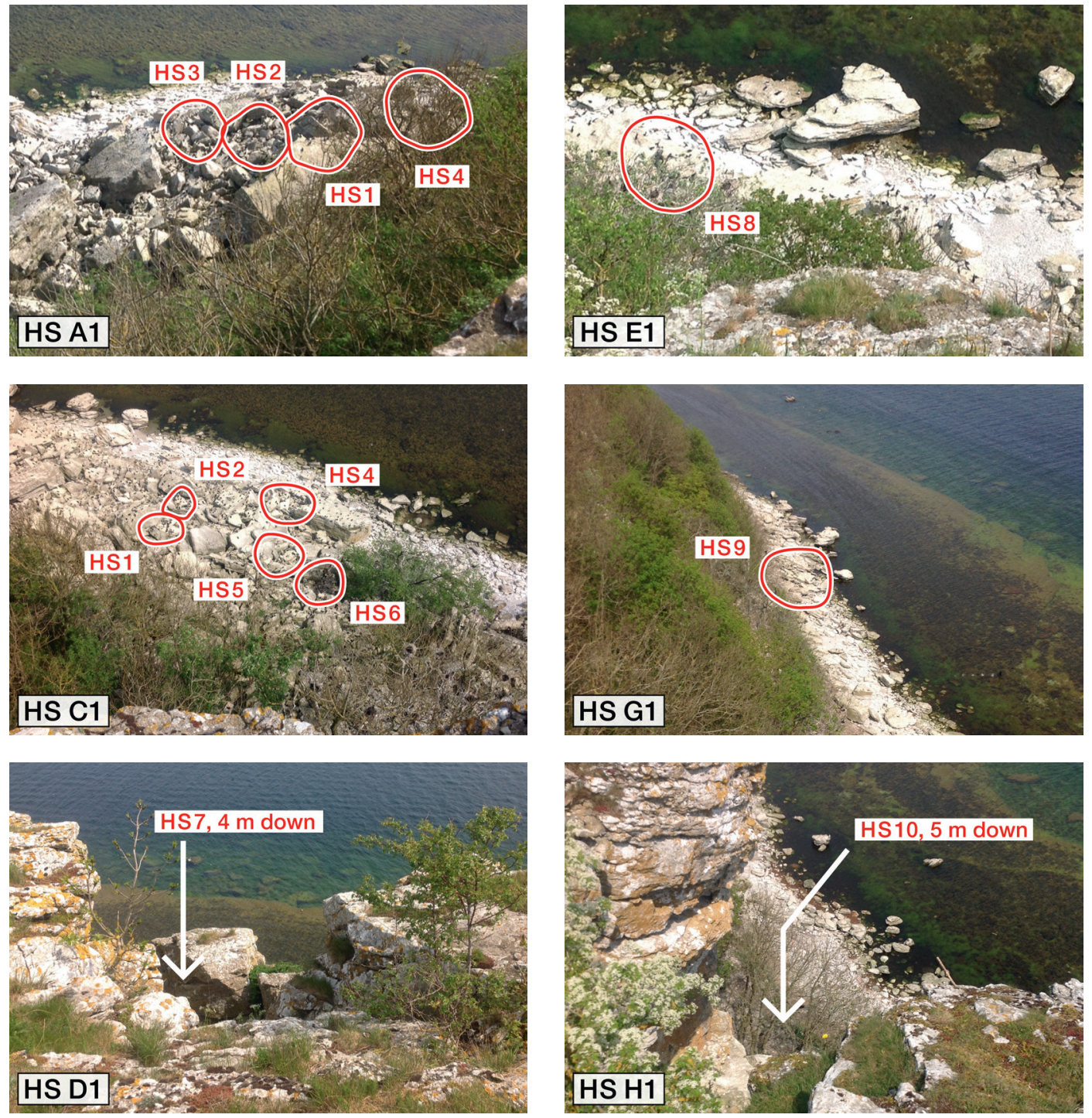

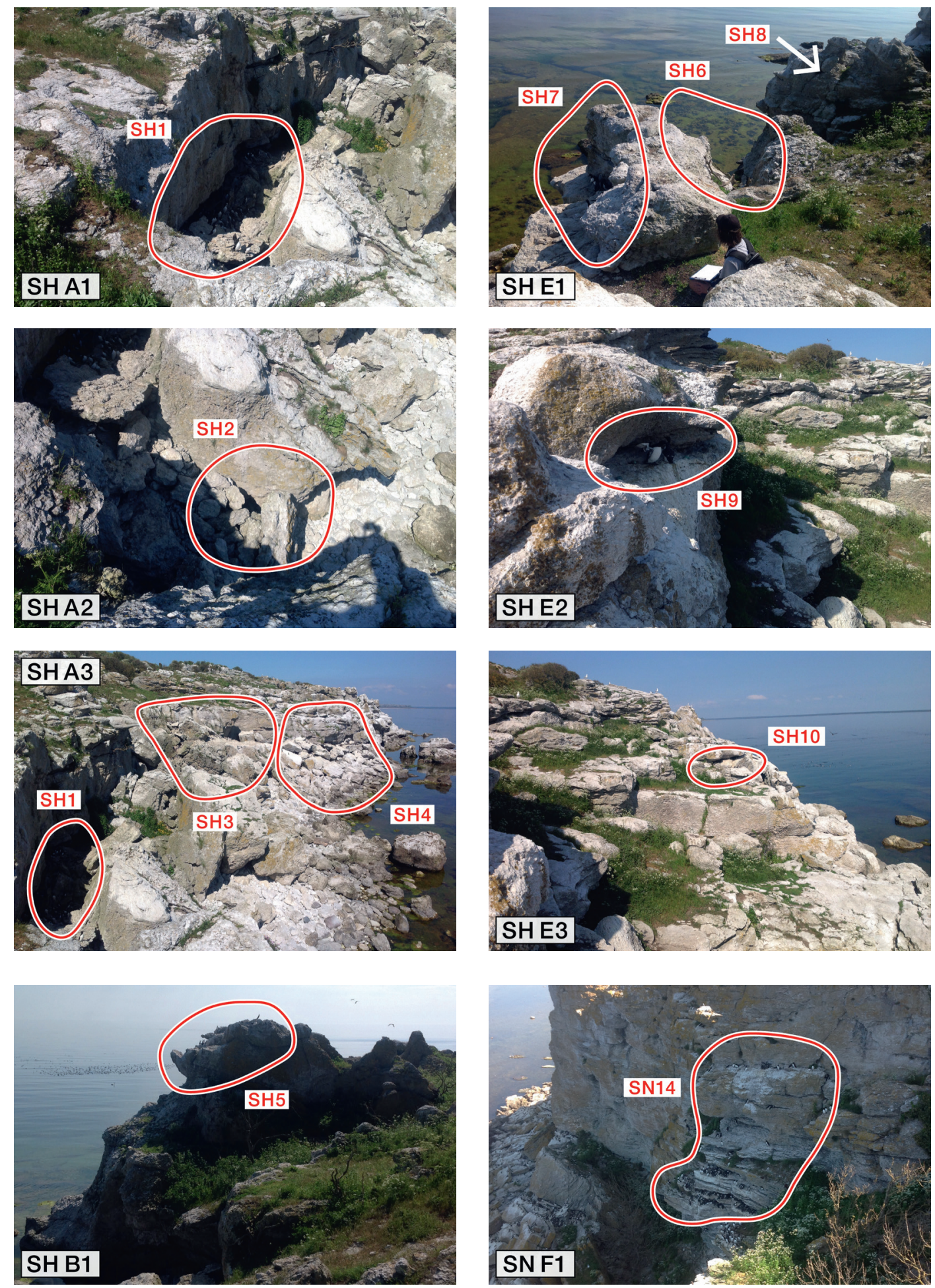

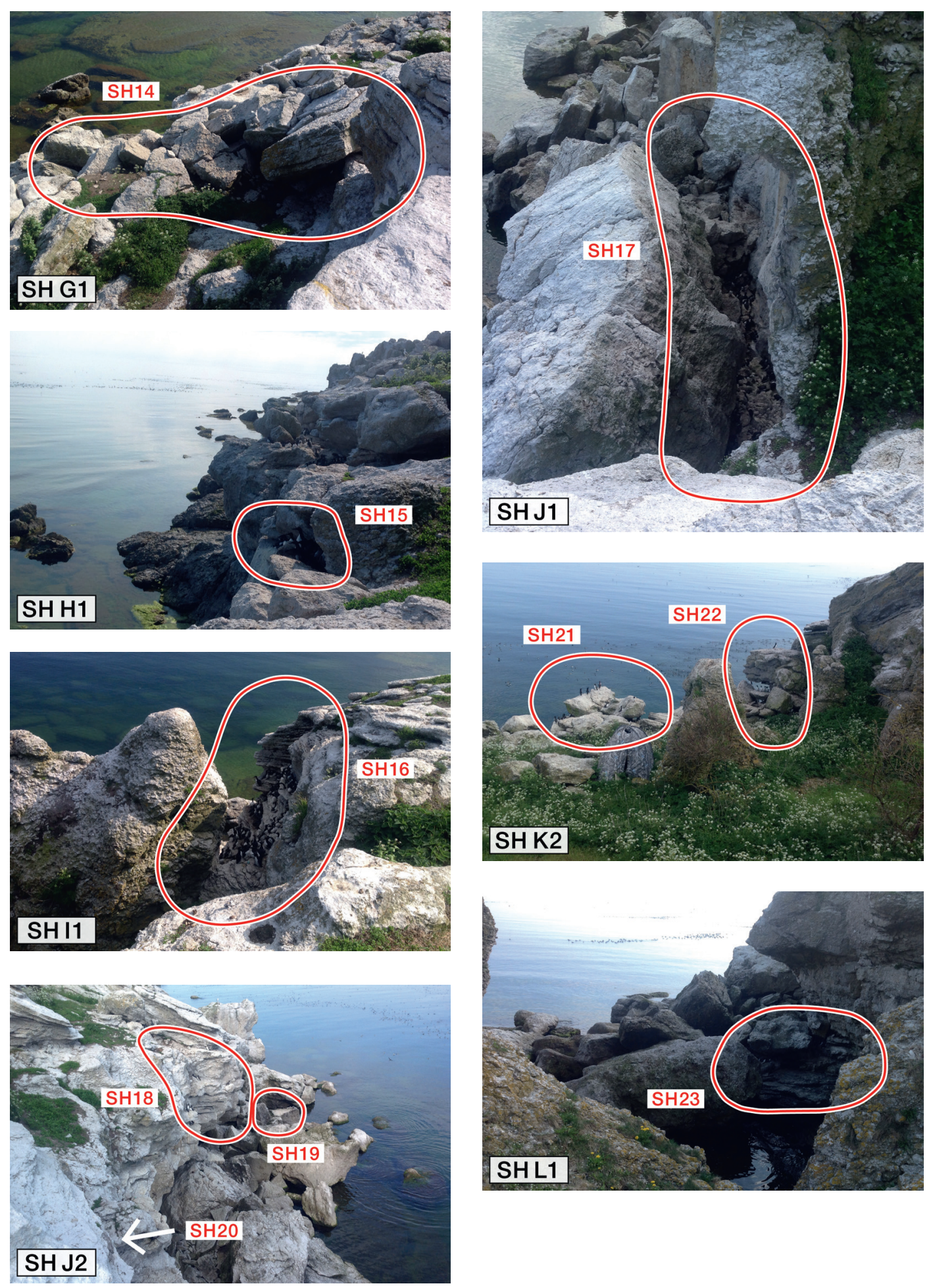

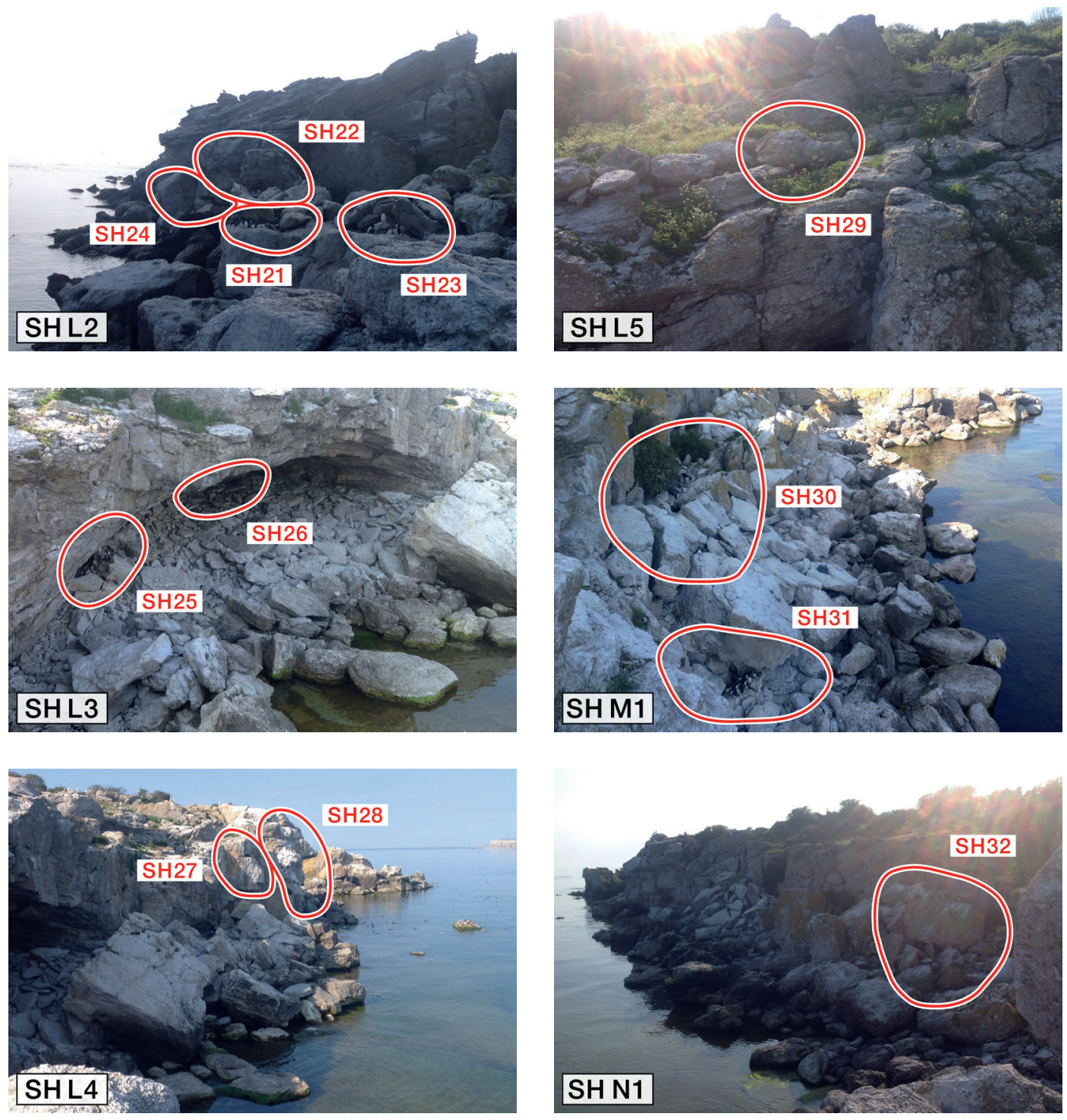

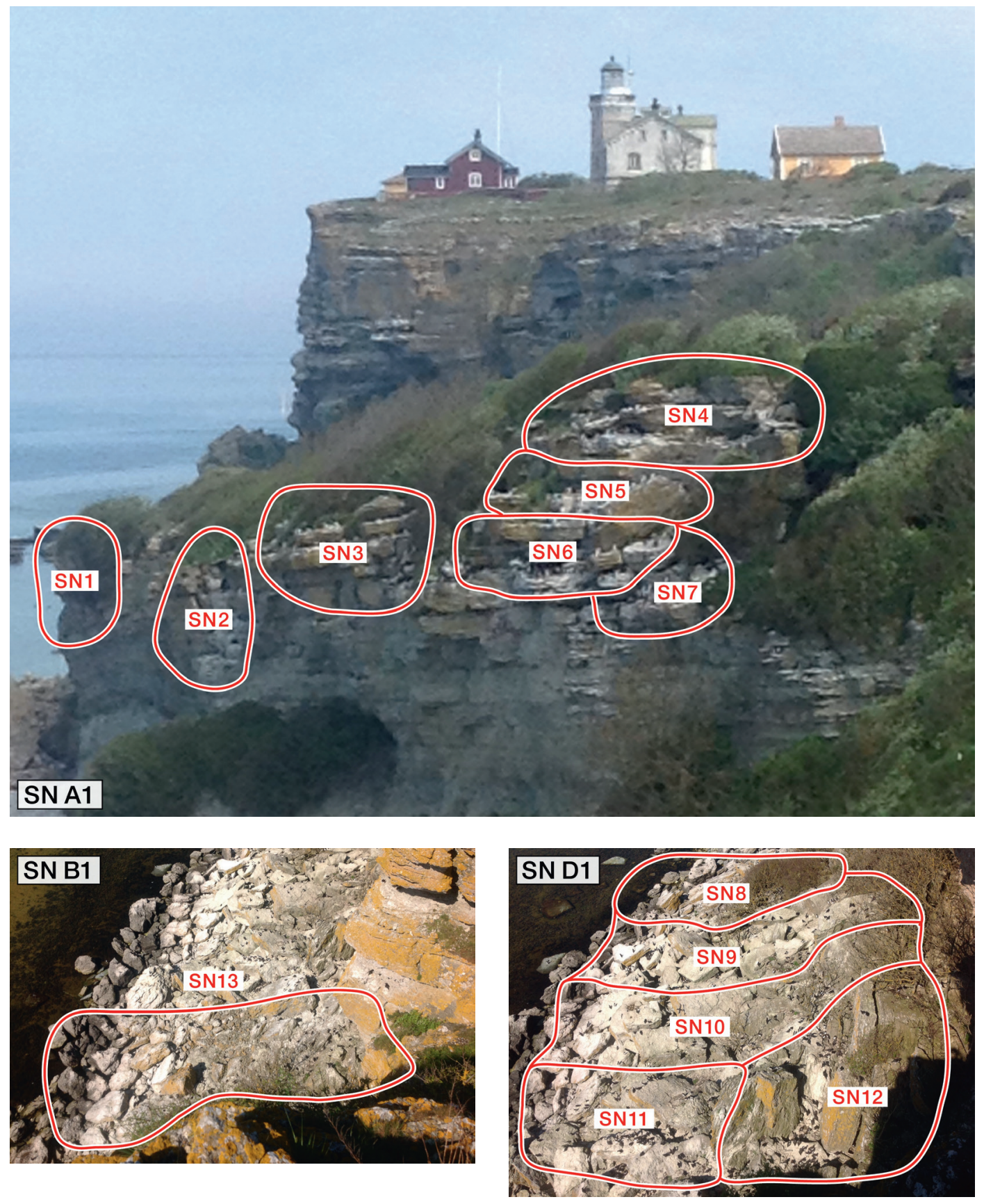

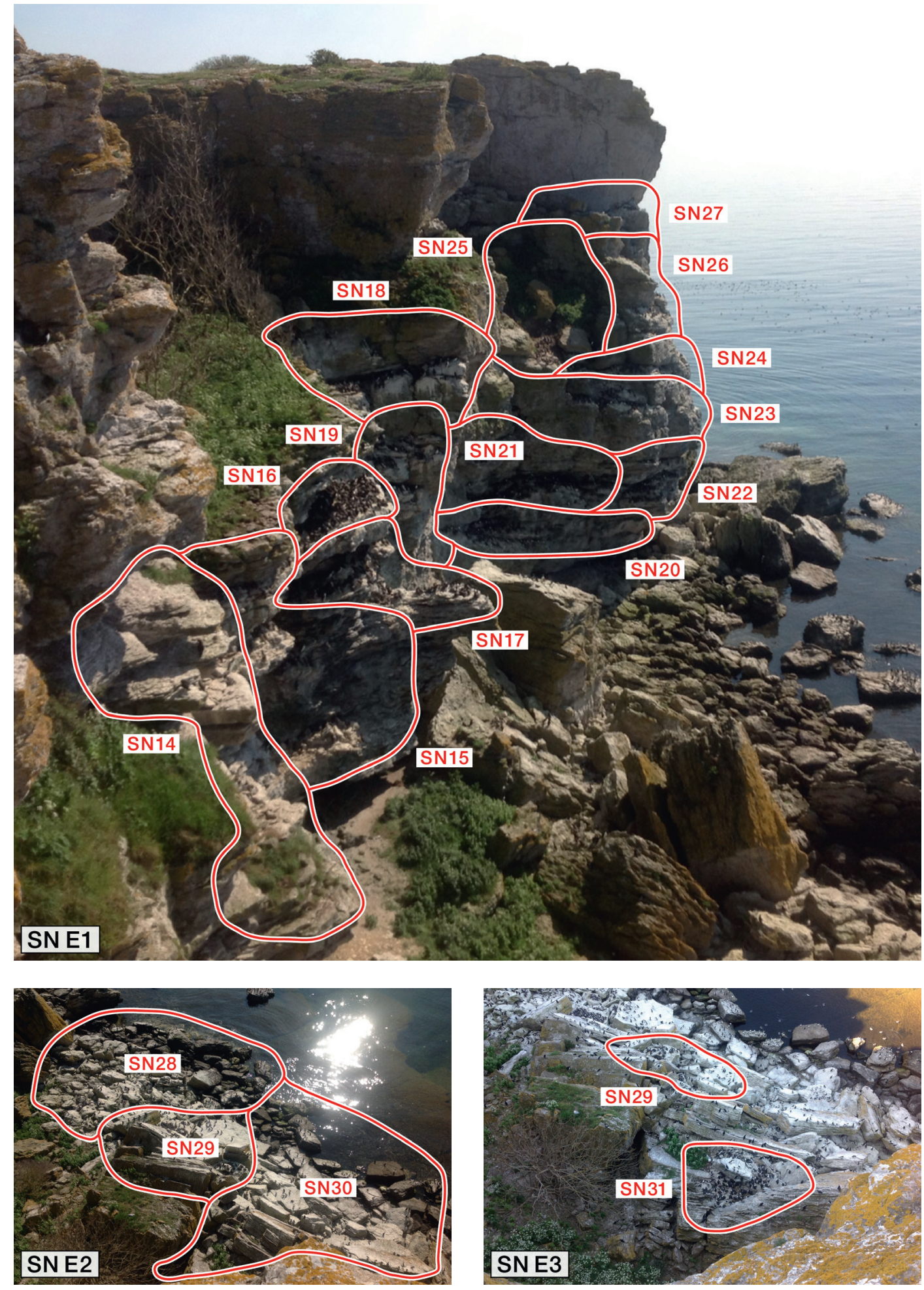

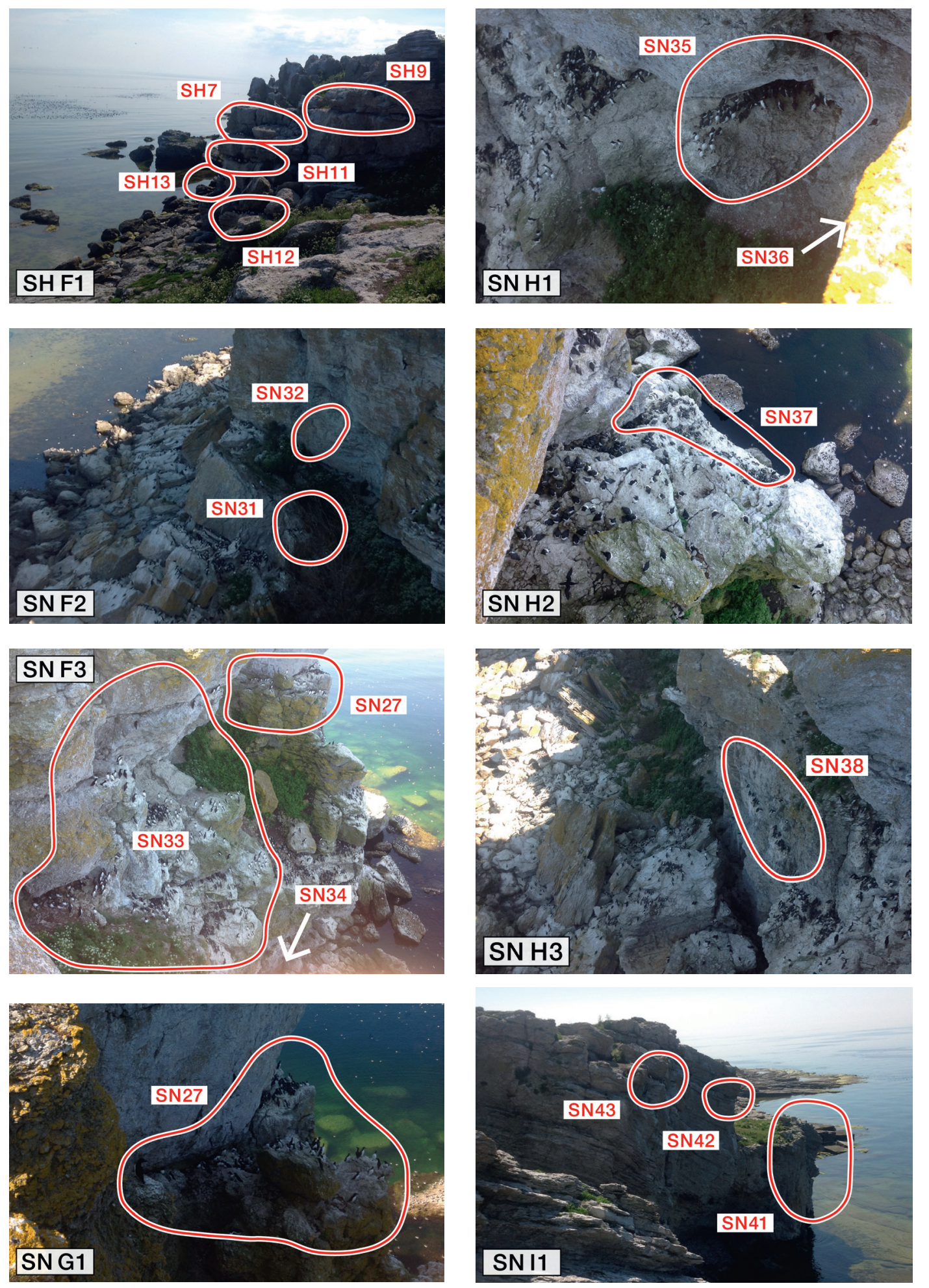

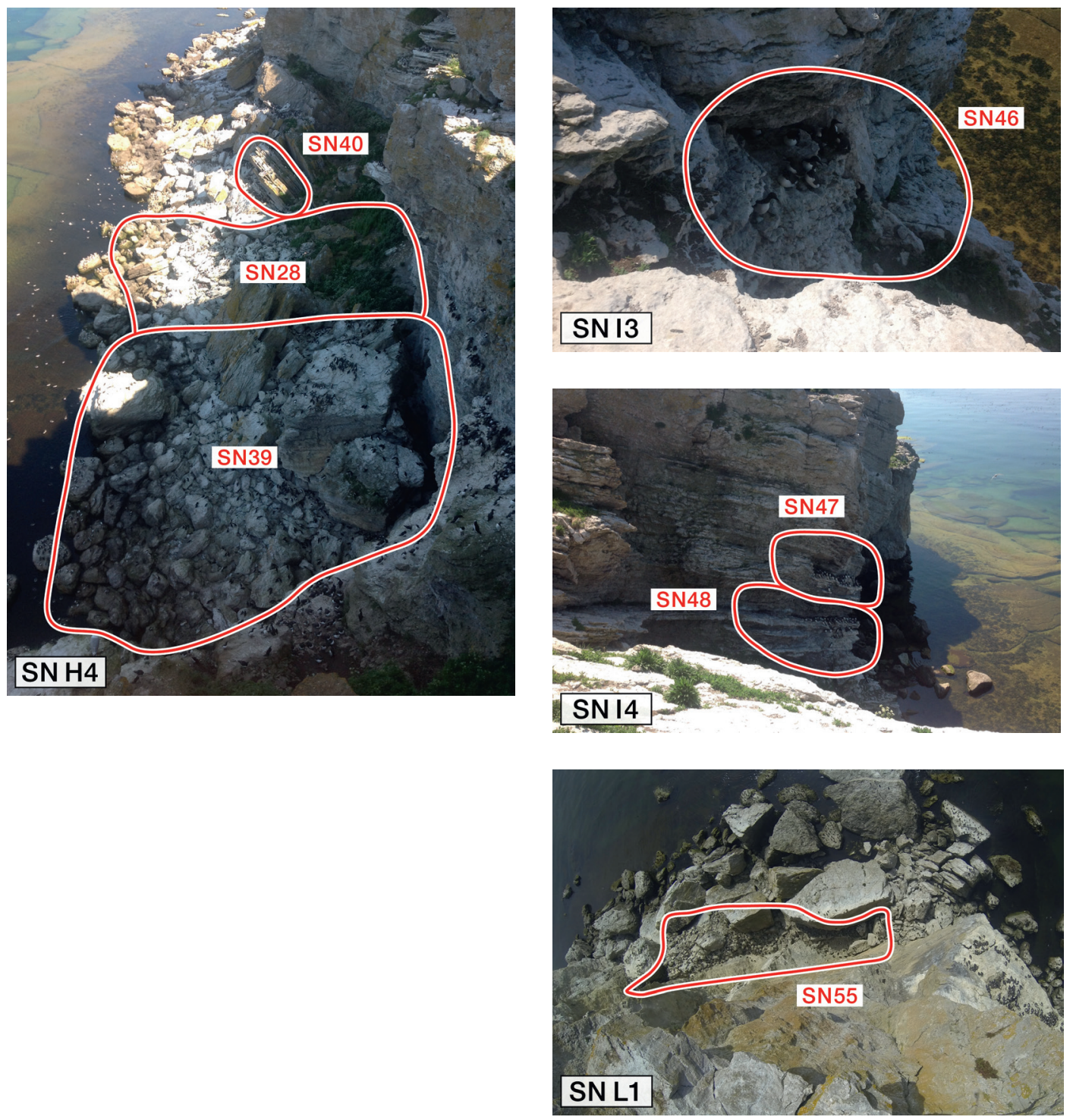

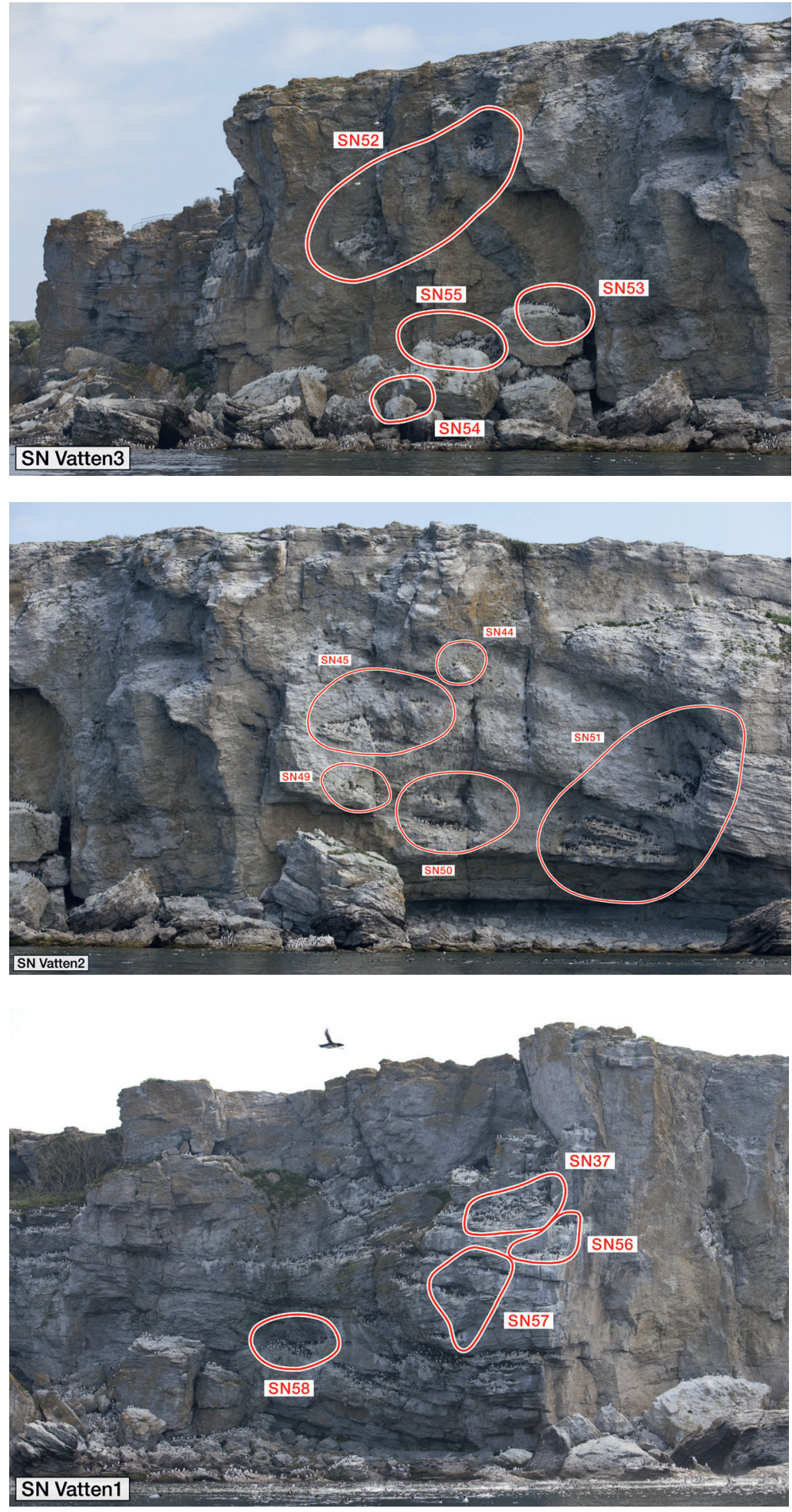

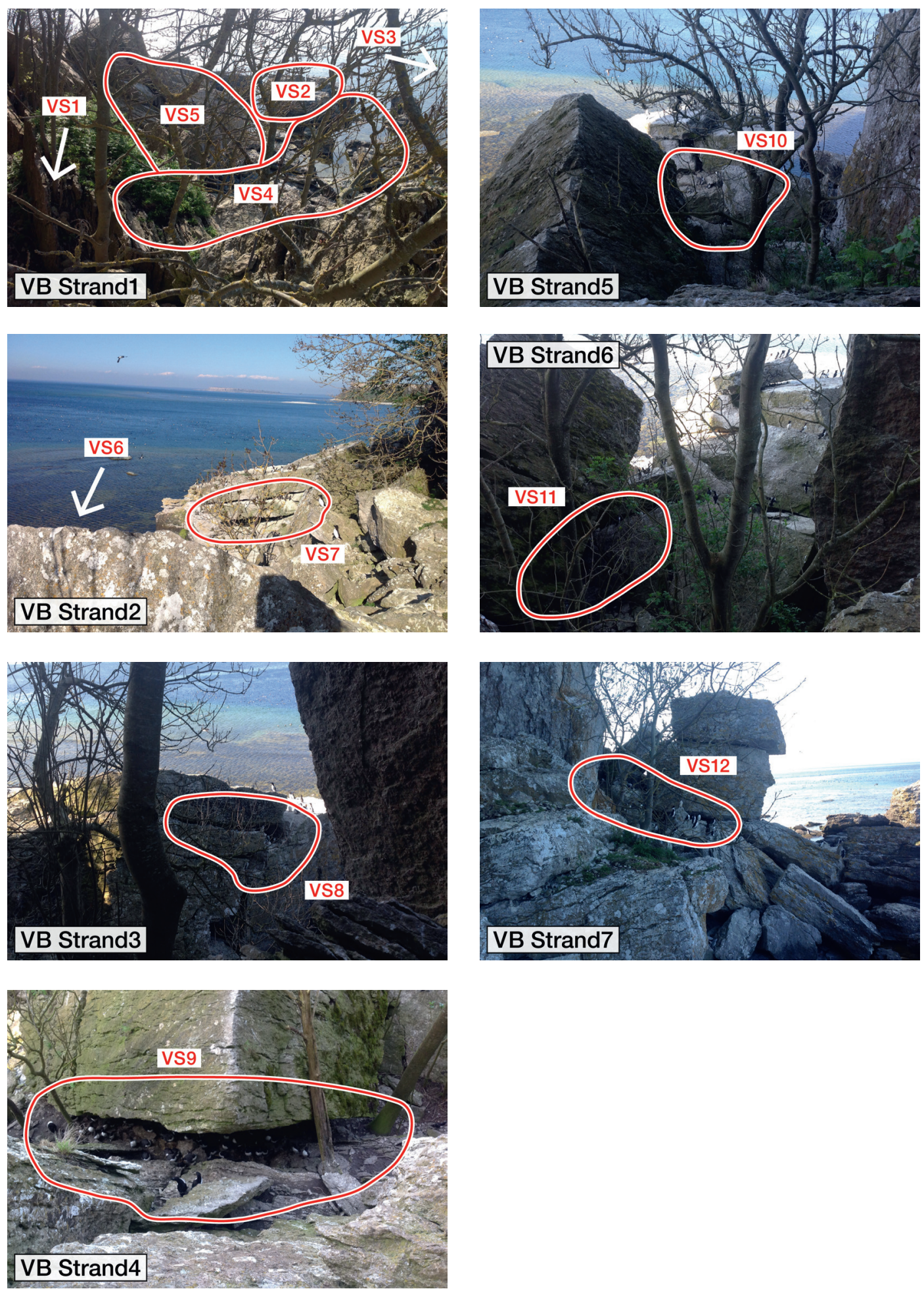

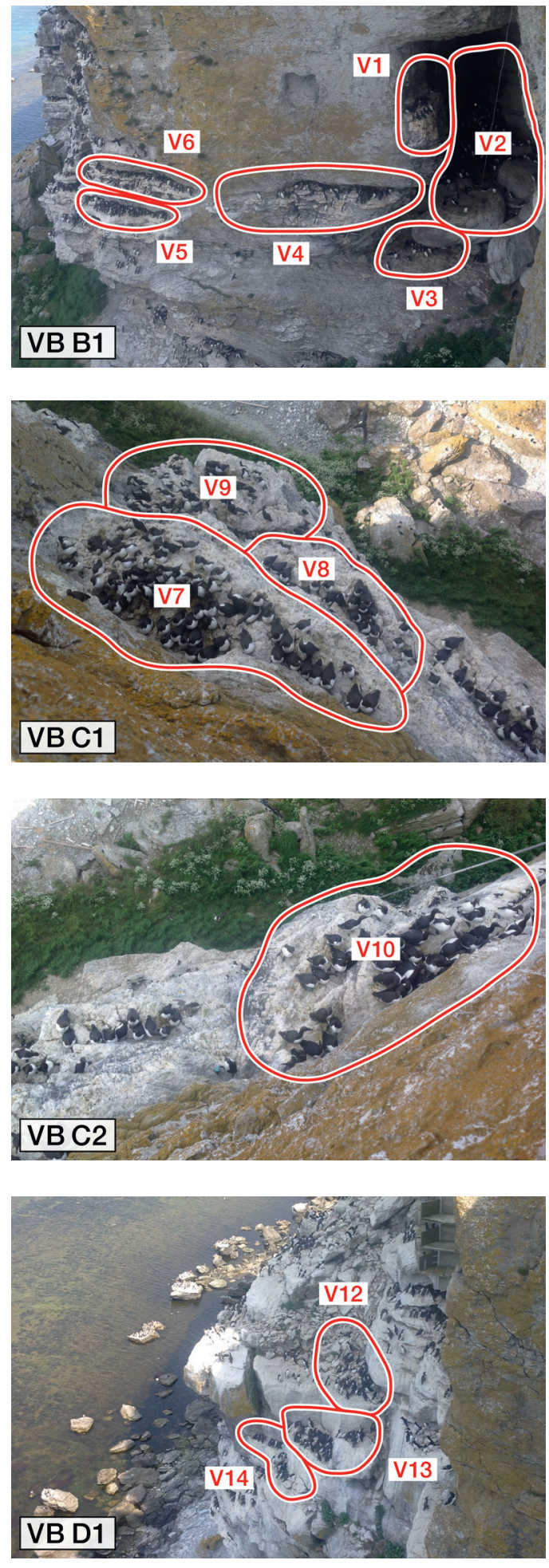
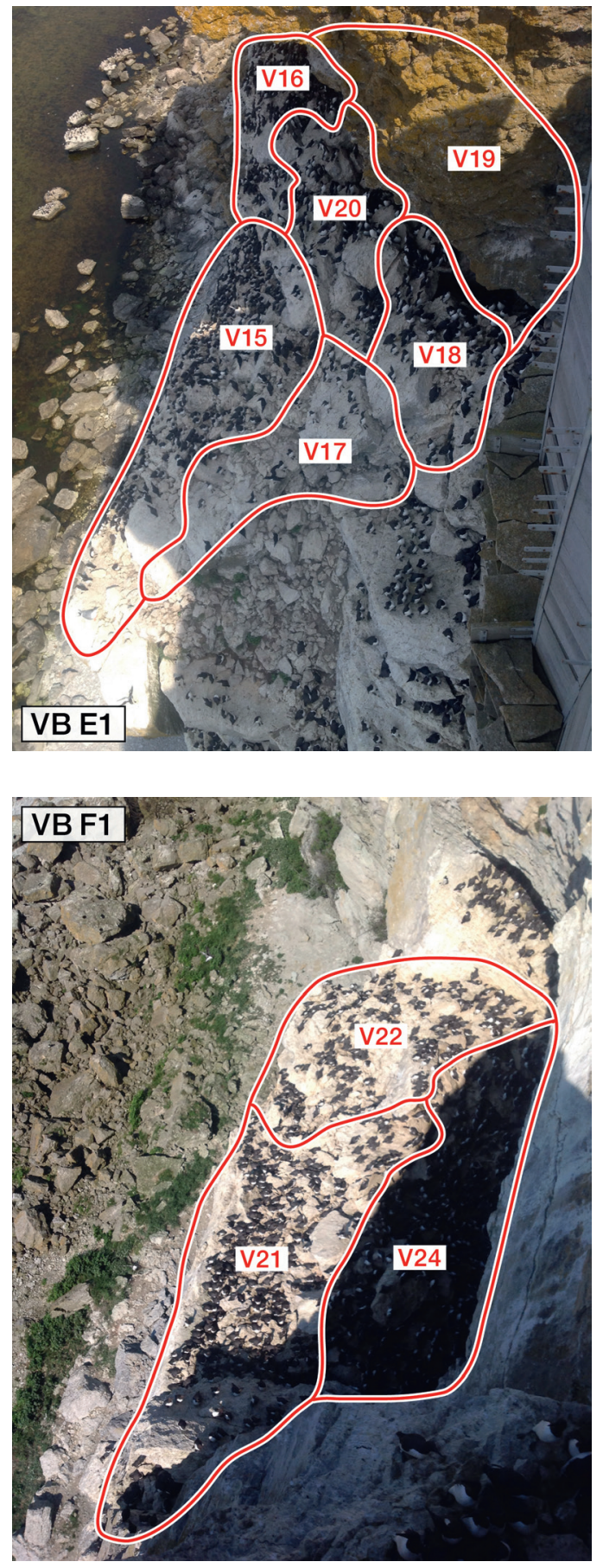

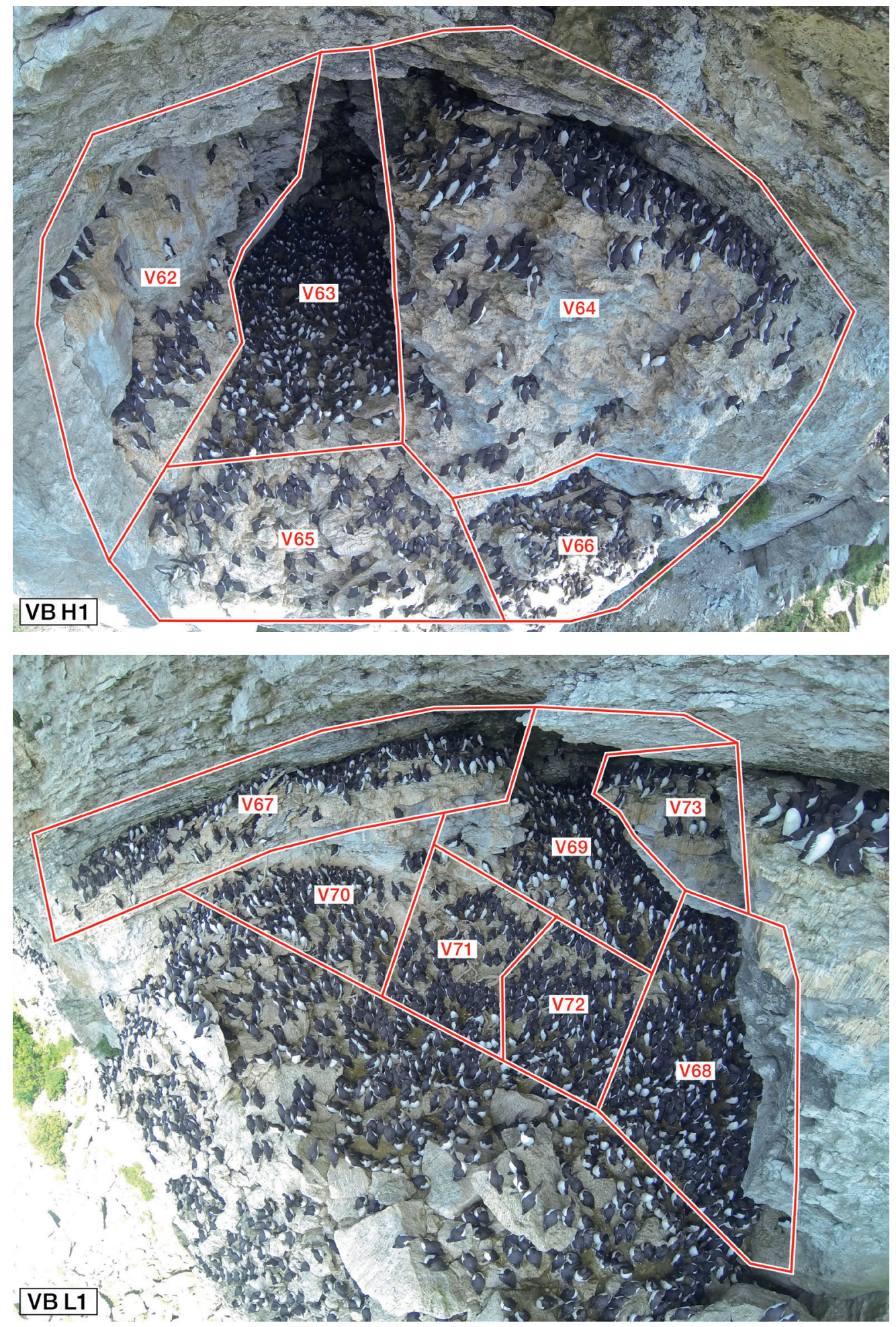

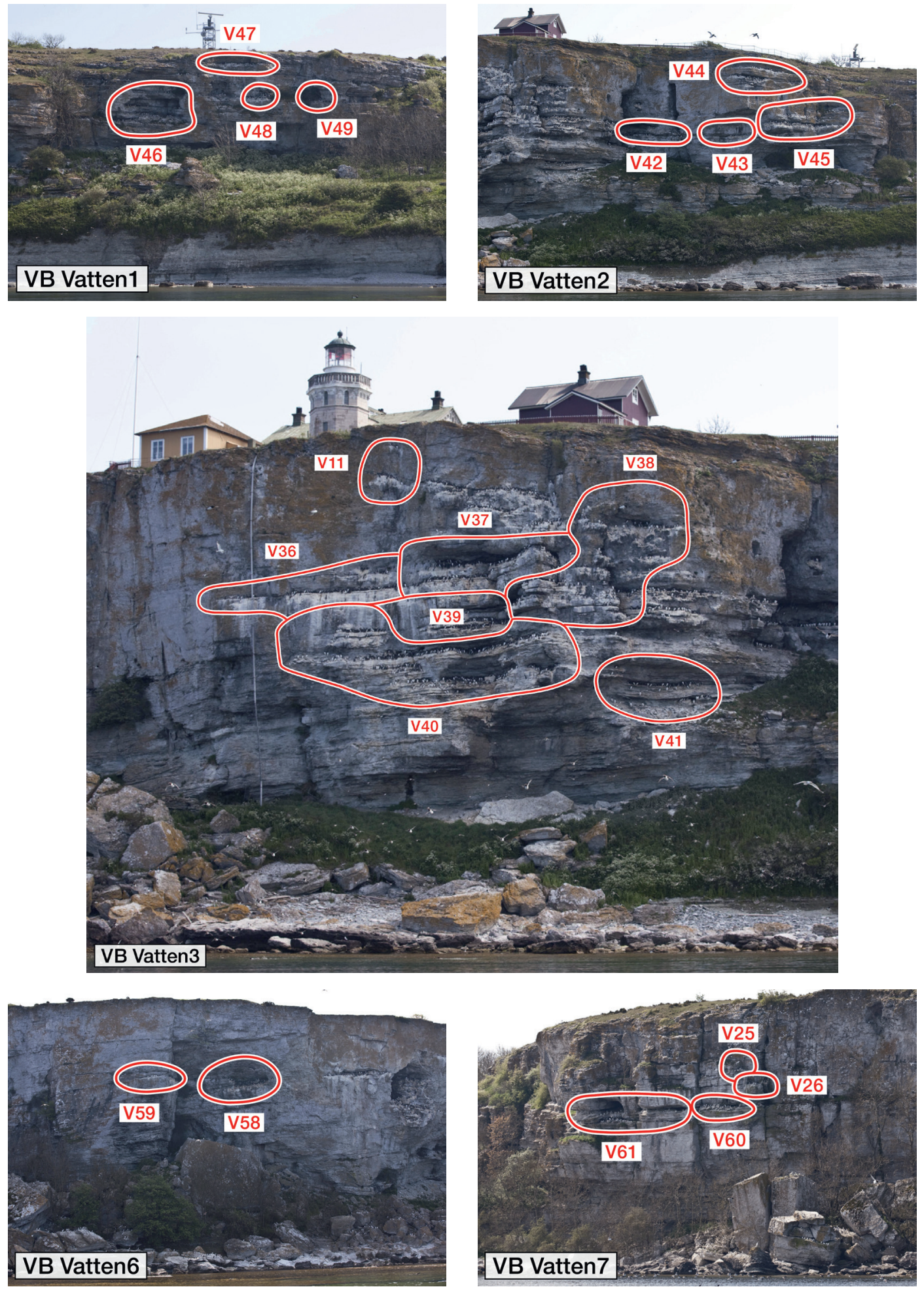

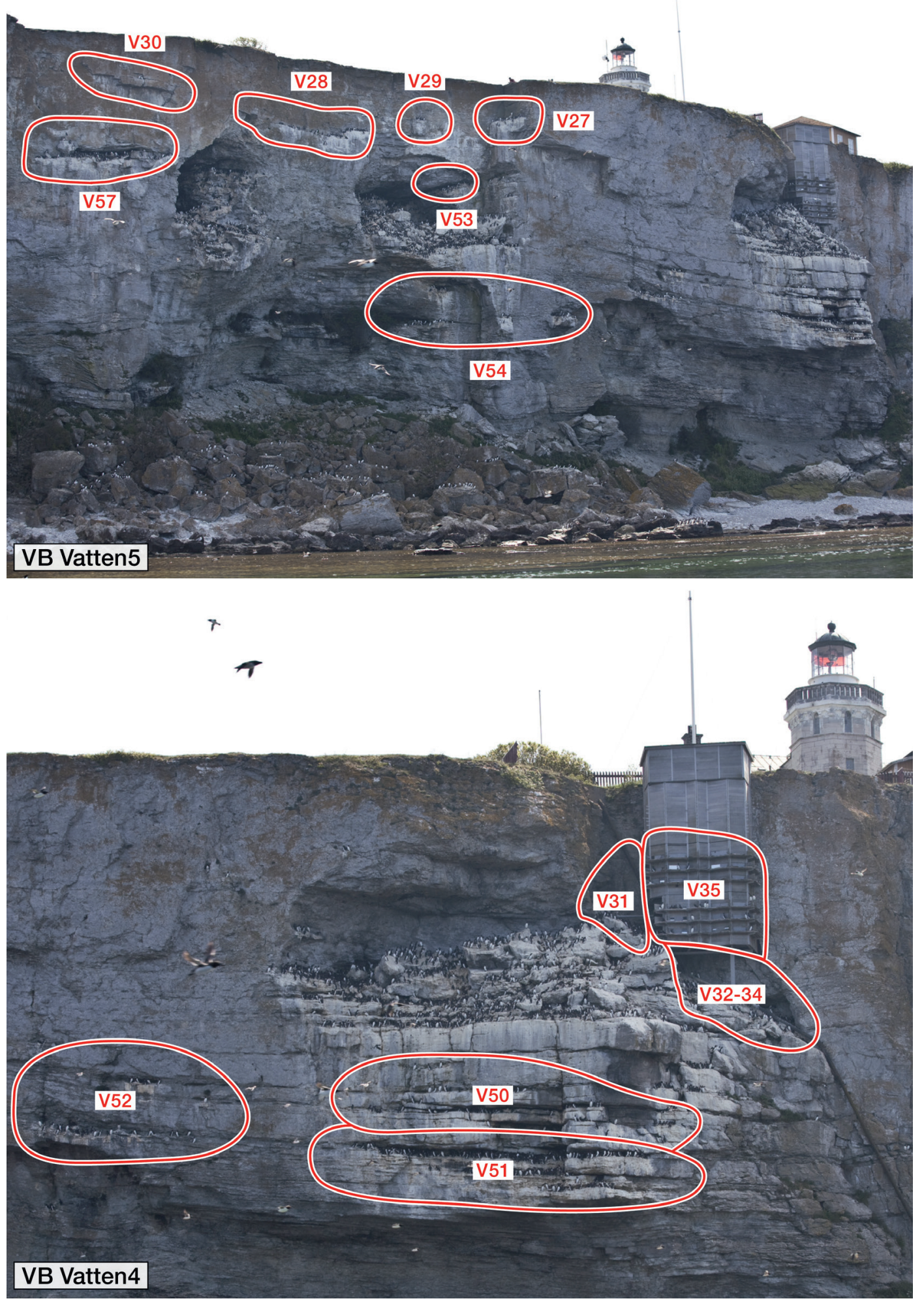